\title{
Örgütsel Sosyalleşmenin Psikolojik Sözleşme ve Örgütsel Bağlılıkla İlişkisi: Bir Kamu Kurumunda Araştırma ${ }^{1}$
}

DOI: $10.26466 /$ opus.674201

\section{Nazlı Türker* - Mustafa Yıldırım **}

* Ar. Gör., Alanya Alaaddin Keykubat Üniversitesi Lisansüstü Eğitim Enstitüsü, Antalya / Türkiye E-Posta: nazli.turker@alanya.edu.tr ORCID: 0000-0003-0318-1700

** Dr. Öğretim Üyesi, Alanya Alaaddin Keykubat Üniversitesi İ.̇.B.F, Antalya / Türkiye

E-Posta: mustafa.yildirim@alanya.edu.tr

ORCID: $\underline{0000-0003-4471-1333}$

\section{Öz}

$B u$ araştırmada çalışanların örgütsel sosyalleşmelerinin ve işe başlarken oluşturdukları psikolojik sözleşmelerinin örgütsel bağhllıkları üzerindeki etkisi incelenmiştir. Ayrıca örgütsel sosyalleşmenin psikolojik sözleşme boyutları üzerindeki etkisi de çalışma kapsamında araştırılmıştır. Bu çalı̧̧manın amacı, Alanya Belediyesi'nde çalışan personelin örgütsel sosyalleşmeleri, psikolojik sözleşmeleri ve örgütsel bağlilıkları arasındaki yordayıcı ilişkileri tespit etmektir. Bu amaç doğrultusunda Alanya Belediyesi'nde çalışan personele anket uygulanmış ve 350 anket değerlendirmeye alınmıştır. Elde edilen veriler, istatistik paket programı ile analiz edilmiş ve öncelikli olarak katılımoı profili ortaya konmuştur. Daha sonra veriler, frekans analizi ve regresyon analiziyle incelenmiştir. Yapılan analizler sonucunda örgütsel sosyalleşmenin psikolojik sözleşme boyutlarından ilişkisel sözleşme üzerinde etkisi bulunmaktadır. Örgütsel sosyalleşmenin örgütsel bağlllık boyutları üzerinde etkisi olduğu sonucuna ulaşılmışıtır. Ayrıca psikolojik sözleşme boyutlarının örgütsel bağhllı üzerinde etkisi olduğu tespit edilmiştir. Örgütsel sosyalleşme, psikolojik sözleşme ve örgütsel bağlllık arasındaki ilişkiyi incelemeye yönelik nispeten az sayıda çalışma olmasından dolayı, bu çalışmanın literatüre katkı sağlaması beklenmektedir.

Anahtar Kelimeler: Örgütsel sosyalleşme, psikolojik sözleşme, örgütsel bağhllık

\footnotetext{
${ }^{1}$ Bu çalışma, Nazlı Türker'in "Örgütsel Sosyalleşmenin Psikolojik Sözleşme ve Örgütsel Bağlııkla Ilişkisi: Bir Kamu Kurumunda Araştırma "başlıklı yüksek lisans tezinden (Alanya Alaaddin Keykubat Üniversitesi Sosyal Bilimler Enstitüsü, 2018) üretilmiştir.
} 


\title{
The Interrelationship Among Organizational Socialization, Psychological Contract And Organizational Commitment: The Research In A Public Institution
}

\begin{abstract}
In this study, the effects of the organizational socialization of the employees and the psychological contracts they form when starting work on their organizational commitment were examined. In addition, the effect of organizational socialization on psychological contract dimensions was also investigated within the scope of the study. The purpose of this study is to determine the predictive relationships between the organizational socialization, psychological contracts and organizational commitment of the personnel, working in Alanya Municipality. For this purpose, a questionnaire was applied to the personnel and 350 questionnaires were evaluated. The data obtained were analyzed with a statistical package program and primarily the participant profile was revealed. Then, the data were analyzed by frequency analysis and regression analysis. As a result of the analysis, organizational socialization has an effect on relational contract, one of the dimensions of psychological contract. It is concluded that organizational socialization has an effect on organizational commitment dimensions. In addition, it has been determined that psychological contract dimensions have an effect on organizational commitment. This study is expected to contribute to the literature, as there are relatively few studies examining the relationship between organizational socialization, psychological contract, and organizational commitment.
\end{abstract}

Keywords: Organizational socialization, psychological contract, organizational commitment 


\section{Giriş}

Birey, içinde yer aldığı toplumda yaşamını sürdürebilmek için gereken bilgileri, değerleri, adetleri o toplumun diğer üyelerinden öğrenir. Bu bilgi ve değerleri kapsayan kültürü içselleştirdikçe o toplumun bir üyesi olmaya başlar. Bireyin bu süreci, sosyalleşme olarak nitelendirilmektedir. Sosyalleşme hayat boyu devam eden bir süreçtir. Örgütsel sosyalleşme, genellikle yeni çalışanın örgüt dışındaki bir bireyden örgütün aktif bir çalışanı haline geçmesi olarak değerlendirilmekle birlikte çalışan yeni bir göreve atandığında ya da yeni bir sorumluluk üstlendiğinde yeniden örgütsel sosyalleşme süreci yaşaması gerekmektedir (Van Maanen ve Schein, 1979, s.6-7). Örgütsel sosyalleşme örgüt ve çalışan arasında, çalışanın örgütün değer sistemlerini, normlarını, davranış biçimlerini öğrendiği bir etkileşim sürecidir (Balc1, 2003: 3). Bireyin çocukluk dönemi sosyalleşmesinde en belirleyici sosyal unsurun aile ve yakın çevre olması gibi; iş yaşamındaki sosyalleşmesinde çalıştı̆̆ örgütteki işverenleri, amirleri, iş arkadaşları en belirleyici sosyal unsurlardır. Örgütsel sosyalleşme sürecinde çalışan hem örgütün ilke, norm, kural ve politikalarını hem de kendi görev ve yükümlülüklerini öğrenir ve benimser (Gökçen Kapusuz, 2019, s.236). Örgütsel sosyalleşme sürecinin başarısı bireyin örgüte ilişkin geliştirdiği olumlu duyguları özellikle örgütsel bağlılığı güçlendirir. Çalışanın işe başladığı andan itibaren, yapacağı işe yönelik bir eğitim alması, bu süreçte örgütün amaç ve değerlerini anlaması, çalışma arkadaşlarının desteğini görmesi ve terfi etmek gibi geleceğe yönelik beklentilerine ilişkin çalışanda olumlu bir kanı oluşması bu süreci pozitif yönde etkiler.

Birey bir işe başlarken zihninde o örgütten kazanabileceklerine dair beklentiler içerisindedir. Bu beklentiler ücret, iş güvencesi, promosyon vb. ekonomik unsurlar olabileceği gibi; tanınma, yükselme, sevdiği işi yapma gibi manevi unsurlar da olabilmektedir. Bireyin bu beklentileri işe alım sürecinde başlar ve örgütsel sosyalleşme aşamasında netleşir. Bireyin örgütten beklentileri olduğu gibi, örgütün de bireyden beklentileri vardır. Bütün bu beklentiler yazılı sözleşmede ele alınmayan, genellikle konuşulmayan, algısal kademede oluşan beklentilerdir (Anderson ve Schalk, 1998, s.638). Bu şekilde taraflar arasında oluştuğu düşünülen sözleşme literatürde psikolojik sözleşme olarak ifade edilmiştir. Bireylerin örgüte giriş anından itibaren örgütte sosyalleşme sürecinin etkin bir şekilde gerçekleşmesi, beklentilerin karşlıklı olarak net bir şekilde ifade edilmesi ve psikolojik sözleşmenin doğru anlaşılması 
için çaba gösterilmesi, örgütlerde uyumlu bir iş ortamının oluşmasına katk1 sağlayacaktır. Böyle bir ortamda çalışan personelin örgütün başarısına çok daha fazla katkıda bulunması ve örgüte daha fazla bağlılık hissetmesi beklenmektedir.

$\mathrm{Bu}$ çalışmada bireylerin örgüte uyumunun sağlanmasında oldukça önemli olan örgütsel sosyalleşme kavramının çalışanların psikolojik sözleşmelerine ve örgütsel bağlılıklarına etkisi araştırılmıştır. Ayrıca psikolojik sözleşme boyutlarının çalışanların örgütsel bağlılık düzeyi üzerindeki etkisi araştırmanın bir diğer sorunsalını oluşturmuştur. Literatürde bu üç değişkeni birlikte ele alan çalışmaların çok sınırlı sayıda olması ve araştırmanın bir kamu kurumunda gerçekleştirilmesi nedeniyle literatüre katkı sağlayacağı beklenmektedir.

\section{Örgütsel Sosyalleşme}

Örgütsel sosyalleşme, yeni işgörenin örgüt içerisindeki görevine yönelik önemli unsurları öğrendiği, işe ve örgüte uyum sağlayabilmesi için eğitim gördüğü bir süreç olarak tanımlanmaktadır (Van Maanen ve Schein, 1979). Thomas ve Anderson'a göre (2005) örgütsel sosyalleşme çalışanın işe alımından sonra, kendisinden beklenenleri yerine getirebilmesi için yaşadığı örgüte uyarlanma ve öğrenme sürecidir. Louis ise (1980b, s.229-230) örgütsel sosyalleşmeyi, bireyin örgütteki görevini öğrenmesi ve örgüte katkı sağlayabilmesi amacıyla gereken değerleri, beklenen davranışları öğrendiği ve sosyal bilgiyi özümsediği bir aşama olarak tanımlamaktadır. Örgütsel sosyalleşme genellikle yeni işgörenin örgüt dışındaki bir bireyden örgütün aktif bir çalışanı haline dönüşmesi süreci olarak ele alınsa da örgütteki bir birey yeni bir göreve atandığında ya da yeni bir sorumluluk üstlendiğinde de bu rolüne uyum sağlamak için yeniden sosyalleşme süreci geçirmesi gerekmektedir. Dolayısıyla örgütsel sosyalleşme, çalışanların örgüte katılmadan önceki döneminde başlayan ve örgütte çalıştığı dönem boyunca devam eden bir süreçtir (Balcı, Baltacl, Cereci ve Acar, 2012).

Literatürde örgütsel sosyalleşme sürecini açılamaya yönelik pek çok yaklaşım mevcuttur. Farklı şekilde sınıflandırılmalar yapılmıştır. Genel olarak örgütsel sosyalleşme araştırmaları üç temel grupta toplanabilmektedir: Birinci grup, sosyalleşme süreci araştırmalarıdır ve bu gruptaki araştırmalar 
daha ağırlıkta olup sosyalleşme aşamaları yaklaşımları olarak sınıflandırılmışlardır. İkinci grup ise sosyalleşme taktikleri ile ilgili araştırmalardır ve örgütsel sosyalleşmede uygulanan taktiklerin nasıl bir örgütsel sonuca ulaştıracağını inceleyen çalışmalardır. Üçüncü grup ise sosyalleşmenin içeriği ile ilgili araştırmalardır ve sosyalleşmenin gerçekleştiği öğrenme alanlarına ve sosyalleşme süresince kazanılanlara odaklanmışlardır.

Aşama modellerinde farklı şekillerde nitelendirilmekle birlikte üç temel aşamadan bahsedilebilir. Bunlar: "giriş öncesi", "giriş" ve "yerleşme" olarak özetlenebilir ve örgütsel sosyalleşmenin ilk dönem çalışmaları ağırlıklı olarak bu sosyalleşme aşamaları üzerine yoğunlaşmıştır (Buchanan, 1974; Feldman, 1976; Wanous, 1980).

Örgütsel sosyalleşmenin taktik modelleri ise örgütlerin yeni personele yönelik bilgi aktarımının gerçekleştirilmesinde ve sosyalleşme deneyimlerini kazandırmada kullanabilecekleri taktikleri içerir. İlk kez Van Maanen (1978) tarafından kolektif ve bireysel, formal ve informal, sıralı ve tesadüfi, sabit ve değişken, seri ve kopuk, atama ve yoksun bırakma olarak altı tane sosyalleşme taktiği geliştirilmiştir. Daha sonra, Jones (1986), bu taktikleri kurumsallaşmışa karşı bireyselleşmiş olmak üzere iki genel boyut altında birleştirmiştir. Kurumsallaşmış taktiklerde, işgörenin işle ilgili detaylı bilgiyi kazandırmaya önem verilmektedir. Bireyselleşmiş taktiklerde ise bireylerin bilgiyi öğrenebilmek için kendilerinin çaba sarf etmesi gerekmektedir (Çerik ve Bozkurt, 2010).

Örgütsel sosyalleşmenin içeriğine odaklanan modeller ise genellikle örgütsel sosyalleşmenin gerçekleştiği öğrenme alanlarına odaklanır. Örgütsel sosyalleşmenin içeriği literatürde pek çok araştırmacı tarafından ele alınmıştir (Chao, O'Leary - Kelly, Wolf, Klein ve Gardner, 1994; Fisher, 1986; Morrison, 1993; Ostroff ve Kozlowski,1992; Taormina, 1994; 1997; 2004). Bu yaklaşımlar, sosyalleşmeyi, hem işverenin çalışanı örgüt için uygun olarak görüp görmeyeceği; hem de çalışanın örgüte adapte olmayı isteyip istemeyeceği çift taraflı bir süreç olarak incelemiştir (Taormina, 1997). Konuyla ilgili ilk çalışmalardan birini yapan Fisher (1986); yeni işgörenin örgütle ilgili öğrenmede bazı konulara dikkat ettiğini belirtmiştir. Bunlar; örgütsel değerler, normlar amaçlar, işyerinin sosyo-kültürel özellikleri, iş yapma şekli, roller ve kimlikler gibi örgütsel ve bireysel değişkenlerdir (Fisher, 1986). Örgütsel sosyalleşme içeriğini inceleyen bir diğer araştırmacı olan Taormina (1994) örgütsel sosyal- 
leşme konusuna örgütsel bakış açısından yaklaşmıştır (Balcı vd., 2012). Bu çalışmada da kullanılan, Taormina'nın (1994) geliştirdiği Örgütsel Sosyalizasyon Envanteri'nin dört boyutu vardır. Bunlar; iş eğitimi, örgütü anlama, mes-

lektaşların desteği ve gelecek beklentisi şeklindedir. Örgütsel sosyalleşmenin ilk düzeyi olan "eğitim" iş için gerekenlerin yeni gelen personel tarafından öğrenildiği süreç olarak tanımlanmaktadır (Taormina, 1997). Örgütsel sosyalleşmeyle ilişkili olarak “örgütü anlama”, bir işgörenin kendi işini, örgütü, diğer işgörenleri anlamasını ve örgüt kültürünü kavramasını ifade etmektedir (Taormina, 1997). Çalışma arkadaşlarının desteği boyutu ise, bireyin çalıştığ örgüte maddi karşılığı olmaksızın, çalışma arkadaşlarından duygusal, manevi ve araçsal olarak gördüğü desteği ve son boyut olan gelecek beklentileri ise, işe yeni başlayan personelin örgütten beklediği kariyer ve yükselme olanakların ifade etmektedir (Taormina, 1997). Özetle, Taormina (1994; 1997) geliştirmiş olduğu bu yaklaşımla örgütsel sosyalleşmenin aşamalı olarak gerçekleşen bir süreç olarak değerlendirilmesinden ziyade, örgütsel sosyalleşmenin gerçekleştiği alanlar üzerine odaklanmıştır ve bunların pek çok örgütsel faktörü etkilediğini belirtmiştir.

\section{Psikolojik Sözleşme}

İş görenler işe başlarken örgütten birtakım beklentiler içerisindedir. Aynı şekilde örgütlerde, işgörenleri belirli beklentiler içerisinde işe almaktadırlar. $\mathrm{Bu}$ beklentilerin yazılı sözleşmelere ilaveten yazılı olmayan, görünmeyen bir sözleşme ile karş1lkklı olarak düzenlenmesi söz konusudur. Argyris [1960], psikolojik sözleşmeyi ilk kez işçi ve işveren arasındaki ilişkileri açıklamak amacıyla kullanmıştır. Agryris'e göre, eğer ustabaşı çalışanların informal şekilde oluşan kültürüne saygı gösterip, işçileri tek başlarına bırakıp, yeterli ücret almalarını sağlayıp, iş güvencelerini garantilerse işçilerin daha yüksek düzeyde üretim yapıp daha az şikayet edeceklerini öne sürmüş ve tam olarak isimlendirmese de psikolojik sözleşme kavramını tanımlamıştır (Anderson ve Schalk, 1998: 638). Kotter (1973) psikolojik sözleşmeyi, birey ile örgüt arasında yazılı olmayan ama sorumluluğunu birbirlerine atfettikleri ve gerçekleşmesini bekledikleri bir anlaşma olarak kavramsallaştırmıştır. Robinson (1996) ise psikolojik sözleşmeyi, işverenin ve çalışanın karşllıklı, birbirlerine ilişkin sorumluluklarını içeren bir kavram olarak tanımlamıştır ve yazılı söz- 
leşmelerin aksine, özünde algısal olduğunu, bir tarafın psikolojik sözleşmeden aldıkları ile diğer tarafın anladıkları arasında fark olabileceğini belirtmiştir.

Psikolojik sözleşme kavramını 1980'li yıllarda inceleyen araştırmacılar yaptıkları çalışmalarda genel olarak iki tür psikolojik sözleşme üzerinde durmuşlardır. İşlemsel sözleşmeler, kısa dönemli, parasal faktörlerin değişimine yönelik, ekonomik boyutu olan sözleşmeler olarak; ilişkisel sözleşmeler ise parasal olan ve olmayan ilişkileri kuran ve sürdüren açık uçlu sözleşmeler olarak tanımlanmaktadır (Rousseau, 1990). Psikolojik sözleşmeler ile ilgili pek çok şekilde sınıflandırma yapılmakla birlikte (Rousseau, 1995; Shore ve Barksdale, 1998); literatürde yaygın olarak, işlemsel ve ilişkisel sözleşmelerin psikolojik sözleşmenin iki boyutu olarak incelendiği görülmektedir.

Psikolojik sözleşme bireysel, örgütsel ve örgüt dışı pek çok faktörden etkilenen, örgütteki işgören ve işveren arasındaki ilişkiyi açıklayan ve örgütlerin başarısına etki eden bir kavramdır. Literatürde genellikle psikolojik sözleşmenin sonuçlarıyla ve ihlal boyutuyla ilgili yapılan çalışmalar yaygın olmakla birlikte bazı çalışmalarda psikolojik sözleşmenin öncüllerine değinilmiştir (Guest, 1998; Rousseau, 2001; Dabos ve Rousseau, 2013). Rousseau (2001)'ya göre, psikolojik sözleşmenin öncüllerini, çalışma öncesindeki deneyimler, stajyerlik dönemi ve işe başlandığı zamandaki sosyalleşme uygulamaları oluşturmaktadır. Guest (1998) ise, psikolojik sözleşmeyi etkileyen faktörleri; örgüt kültürü ve iklimi, insan kaynakları uygulamaları, deneyim, beklentiler ve diğer alternatifler olarak sınıflandırmıştır. Psikolojik sözleşme sonuçları bakımından çok sayıda bireysel ve örgütsel faktörle ilişkilendirilmiştir (Aselage ve Eisenberger, 2003; Coyle-Shapiro ve Kessler, 2003; Estreder, Tomás, Chambel, ve Ramos, 2019; Guest, 1998; Parzefall ve Hakanen, 2010; Robinson ve Rousseau, 1994; Soares ve Mosquera, 2019; Sturges, Conway, Guest, Liefooghe, 2005; Zhou, Plaisent, Zheng ve Bernard, 2014).

\section{Örgütsel Bağlılık}

Örgütsel bağlılık konusu, farklı disiplinlerce sıklıkla incelenen, bireysel ve örgütsel çok sayıda değişkenle ilişkilendirilerek araştırılan bir konudur. Literatürde bu kavramla ilgili pek çok tanım yapılmıştır. Grusky tarafından, 1966 yılında yapılan örgütsel bağlılık tanımı bu konuyla ilgili ilk tanımlamalardan birisidir. Bu tanıma göre örgütsel bağlllık, üyenin bir bütün olarak sistemle 
ilişkisinin niteliğidir (Grusky, 1966). Kanter (1968), bağlılı̆̆ı, sosyal aktörlerin güçlerini ve sadakatlerini sosyal sistem için kullanmak amaciyla arzu duymaları, kişilik sistemleri ile sosyal ilişkiler arasında ilişkinin oluşması şeklinde tanımlamaktadır. Reichers (1985), örgütsel bağllı̆̆ı tek boyutlu bir kavram olarak değerlendirmekten ziyade çok boyutlu olarak ele alınması gerektiğini öne sürmüş ve örgütü oluşturan çoklu öğeler ile özdeşleşme süreci olarak incelemiştir. Örgütsel bağl1lık konusunda en sık kullanılan yaklaşımlardan birini geliştiren Meyer ve Allen (1991: 97) ise, örgütsel bağlllı̆̆1, işgörenlerin örgütle ilişkisinden etkilenen ve örgüt üyeliğine katılma isteği duymalarını sağlayan bir kavram olarak nitelendirmişlerdir ve örgütsel bağlılı̆̆ın psikolojik bir boyutu olduğunu belirtmişlerdir. Bayram (2005: 128) örgütsel bağlılı̆̆g, "işgörenlerin örgütte kalmak istemeleri, örgütün tüm etkinliği, ç1karı ve başarısı ile kimliklenme, işgörenin örgüte karşı olan sadakat tutumu ve çalıştı̆̆ örgütün başarılı olabilmesi için gösterdiği ilgi" olarak tanımlamıştir.

Örgütsel bağlllık çalışanın işe girmesiyle başlayıp, örgütün bir üyesi olarak örgütün hedeflerini, amaçlarını ve işin gerekliliklerini öğrenmesiyle devam eder. Örgütüne bağlllık hisseden bir bireyin görevini yerine getirmede daha çok çaba göstermesi ve uzun yıllar o örgütte çalışması beklenmektedir. Örgütsel bağlılığı yüksek olan çalışanların örgütleriyle daha uyumlu olması ve katkısının çok daha fazla olması söz konusudur.

Örgütsel bağllı̆̆ın sınıflandırmasında çeşitli araştırmacılar, farklı kriterleri ele alarak pek çok model önermişlerdir. Günümüzde de geçerliliğini koruyan ve örgütsel bağlılık konusunda yapılan çalışmalarda sıklıkla kullanılan sınıflandırmalardan birisi Allen ve Meyer (1990) tarafından oluşturulmuştur. Bunlardan biri duygusal bağlılıktır. Örgütlerde çalışanların geliştirmesi en çok arzu edilen bağlılık türü olan duygusal bağlılık, çalışanların ihtiyaçlarından ziyade örgütte kalmayı gerçekten istemelerinden kaynaklanan bağlılıktır. Devam bağlılığı ise örgütten ayrılmanın sonuçlarını değerlendirerek bulunduğu örgütte çalışmaya devam etmekle ilişkili olan bağlllıktır. Bu bağlllık türünde çalışanların örgütte kalmak istemelerinin temel nedeni örgütte kalmaya ihtiyaçlarının olmasıdır (Meyer ve Allen, 1991). Normatif bağlılık ise bir görev bilinciyle çalışanın örgütte kalmaya devam etmesiyle ve örgütte çalışmayı bir minnet duygusu olarak görmesiyle açıklanabilen bir boyuttur. $\mathrm{Bu}$ bağllılı türü devam bağlılığındakinden farklı bir zorunluluk içermektedir. Normatif bağlılık boyutundaki zorunluluk, devam bağllı̆̆ında olduğu gibi 
çıkara bağlı değil, bağlılık duymalarının ahlaki olduğunu düşünmelerine dayanmaktadır (Gül, 2002, s.46). Özetle, duygusal bağlllık, kişiler o örgütte kalmayı istedikleri için; devam bağlılığı çıkarları o örgüte bağlanmayı gerektirdiği için ve normatif bağlllık ahlaki açıdan örgüte bağlanmayı doğru buldukları için ortaya çıkmaktadır (Allen ve Meyer, 1990). Literatürde örgütsel bağlılığı öncülleri ve sonuçları bakımından çeşitli örgütsel faktörlerle ilişkilendiren çok sayıda çalışma bulunmaktadır (Agarwal ve Sajid, 2017; Avcı ve Küçükusta, 2009; Balfour ve Wechsler, 1996; Bilgili ve Tekin, 2019; Büyükbeşe, Çavuşoğlu ve Okun, 2019; Gül, 2003; Meyer, Irving ve Allen, 1998; Sürgevil, 2007; Özutku, 2008; Valaei ve Rezaei, 2016; Yazgan ve Özer Topaloğlu, 2020).

\section{Araştırmanın Önemi}

Örgütsel sosyalleşme ve psikolojik sözleşme, işgörenlerin örgütün aktif bir üyesi haline dönüşmesi ve örgüte olan bağlllığının sağlanması açısından oldukça önem taşıyan kavramlardır. Birey yeni bir işe başladığında ya da yeni bir göreve atandığında, kendisi için değişik ve belirsiz bir çevreye girmiş olmaktadır. Bu aşamada örgütsel sosyalleşme süreci kritik bir rol oynamaktadır ve çalışanın zihninde oluşturduğu psikolojik sözleşmesinde değişikliklere yol açabilmektedir. Örgütsel sosyalleşme ile yapılan literatür incelemesinde ağırlıklı olarak eğitim sektörü üzerine yapıldığı, son yıllarda diğer sektörler açısından da ele alındığı görülmüştür. Özellikle kamu sektöründe yapılan çalışmalar sınırlı sayıdadır. Yine yapılan literatür incelemesinde, örgütsel sosyalleşme ve psikolojik sözleşme kavramlarının ayrı ayrı örgütsel bağlılık ile ilişkilendirildiği pek çok çalışma olduğu görülmüştür. Fakat, örgütsel sosyalleşme kavramı ve psikolojik sözleşme kavramının birlikte incelendiği az sayıda çalışma bulunmaktadır (De Vos, Buyens ve Schalk, 2003; Kim ve Moon, 2019; Manuti, Spinelli ve Giancaspro, 2016; Thomas ve Anderson, 1998; Woodrow ve Guest, 2020). Bu çalışmanın sonuçlarının, kamu kurumları açısından faydalı olacağı öngörülmektedir. Konu ile ilgili kamu sektörü ve özel sektör ile ilgili yapılacak olan daha sonraki çalışmalar için katkı sağlayacağı düşünülmektedir.

\section{Araştırmanın Amacı ve Hipotezleri}

Araştırmanın konularına yönelik teorik çerçeve ve araştırma konuları arasındaki ilişkiler dikkate alınarak yapılan bu araştırmanın amacı; Alanya Belediyesi'nde çalışan personelin örgütsel sosyalleşmeleri, psikolojik sözleşmeleri 
ve örgütsel bağlılıkları arasındaki yordayıcı ilişkileri tespit etmek olarak belirlenmiştir. Bu amaç çerçevesinde ilgili teorik çerçeve ve ampirik sonuçlar doğrultusunda araştırma hipotezleri geliştirilmiştir. Öyle ki; bireyin yeni bir işe başlaması ve o işin gerektirdiklerini öğrenmesi, o örgüte uyum sağlamaya çalışması bireylerde kaygı oluşturan bir durumdur. İş görenler zamanla, işe ve örgüte yönelik çeşitli bilgiler kazanmakta ve böylece örgütlerin kendilerinden neler beklediğini belirginleştirmekte ve rollerinin neler olduğunu öğrenmekte (Hiltrop, 1995) ve bu tür bilgilerin öğrenilmesi ile iki tarafın beklentileri oluşmaktadır. Böylece, karşılıklı olarak psikolojik sözleşme ortaya çıkartılmış ve yenilenmiş olmaktadır (Thomas ve Anderson, 1998). Psikolojik sözleşmenin oluşum zamanı ile ilgili literatürde, işgörenin örgüte katılmadan önce, işe giriş aşamasında örgütle ilgili yaptığı araştırmalar sırasında oluşmaya başladığı ve işe başladıktan sonra sosyalleşme süreciyle birlikte olgunlaşmaya başladığı düşüncesi yaygındır. Taormina (1994) tarafından geliştirilen örgütsel sosyalleşmenin boyutları, psikolojik sözleşmenin oluşumu ve gelişimi açısından oldukça önemli sayılabilir. İş eğitimi, örgütü anlama, çalışma arkadaşlarının desteği ve gelecek beklentileri boyutları, çalışanın psikolojik sözleşmesinin şekillenmesini ve değişimini etkileyebilecek unsurlardır. Literatürde psikolojik sözleşme ile ilgili çalışmalar genellikle psikolojik sözleşmenin oluşumu, psikolojik sözleşmenin ihlali ve sonuçları üzerinde yoğunlaşmıştır. Örgütsel sosyalleşme, psikolojik sözleşme ve örgütsel sonuçları arasındaki ilişkiyi ve psikolojik sözleşmedeki değişimi inceleyen nispeten az sayıda çalışma bulunmaktadır (Debode, Mossholder ve Walker, 2017; De Vos vd., 2003; Robinson, Kraatz ve Rousseau, 1994; Thomas ve Anderson, 1998; Woodrow ve Guest, 2017). Tekleab, Orvis ve Taylor (2013) işe yeni başlayan çalışanların, işveren temelli psikolojik sözleşme yükümlülüklerine ilişkin algıladıkları değişimi inceledikleri çalışmada, değişimi algılanan psikolojik sözleşme ihlali ve çalışan tutum ve davranışlarının önemli bir belirleyicisi olarak varsaymaktadır. Üç aşamalı boylamsal bir araştırma deseni oluşturulmuştur. Yeni işe başlayanların, ilk yılda işveren temelli ilişkisel yükümlülüklerinde önemli ölçüde azalma olduğu ve bu değişikliklerin çalışanlar tarafından olumsuz karşılandığı, psikolojik sözleşmenin ihlalinde artış, artan işten ayrılma, azalan iş tatmini ve örgütsel bağlllık gibi negatif tutumlara yol açtığ sonuçlarına ulaşılmıştır. Manuti vd. (2016) yapmış oldukları çalışmada etkili bir psikolojik sözleşmenin oluşturulması ve örgütsel sosyalleşme sürecinin 
başarısı arasındaki ilişkiyi incelemişlerdir. Yapılan hiyerarşik regresyon analizi sonucunda örgütsel sosyalleşmenin duygusal bağlllığın önemli bir belirleyicisi olduğu, ilişkisel sözleşmenin de duygusal bağlllık ile önemli ölçüde ilişkili olduğu belirlenmiştir. Örgütsel sosyalleşmenin, ilişkisel ve dengeli sözleşmenin, iş tatmininin önemli bir belirleyicisi olduğu ortaya çıkmıştır. Yukarıda sunulan görüş ve bulgulardan hareketle araştırmanın, örgütsel sosyalleşme ve psikolojik sözleşme ilişkisine yönelik hipotezleri şu şekilde oluşturulmuştur:

- H1: Örgütsel sosyalleşmenin iş eğitimi boyutunun, işlemsel sözleşme üzerinde negatifbir etkisi vardir.

- $\quad H_{2}$ Örgütsel sosyalleşmenin örgütü anlama boyutunun, işlemsel sözleşme üzerinde negatif bir etkisi vardir.

- H3: Örgütsel sosyalleşmenin çalışma arkadaşlarmnn desteği boyutunun, işlemsel sözleşme üzerinde negatif bir etkisi vardır.

- $\quad H_{4}$ : Örgütsel sosyalleşmenin geleceğe ilişkin beklentiler boyutunun işlemsel sözleşme üzerinde negatif bir etkisi vardır.

- H5: Örgütsel sosyalleşmenin iş eğitimi boyutunun, ilişkisel sözleşme üzerinde pozitifbir etkisi vardir.

- H6: Örgütsel sosyalleşmenin örgütü anlama boyutunun, ilişkisel sözleşme üzerinde pozitif bir etkisi vardir.

- H7: Örgütsel sosyalleşmenin çalışma arkadaşlarmın desteği boyutunun, ilişkisel sözleşme üzerinde pozitif bir etkisi vardır.

- Hs: Örgütsel sosyalleşmenin geleceğe ilişkin beklentiler boyutunun ilişkisel sözleşme üzerinde pozitifbir etkisi vardır.

Örgütsel sosyalleşme uygulamalarının başarılı olduğunun önemli göstergelerinden birisi de çalışanların örgüte duydukları bağlılıktır. Sosyalleşme uygulamalarının yapısal özelliklerine karşılık, sosyalleşme sürecinde aktarılan bilgilerin içeriğinin örgütsel bağlılı̆̆ı oluşturma açısından oldukça önemli olduğu ileri sürülmüş ve bunu açıklamak için Chao vd. (1994) tarafından örgütsel sosyalleşme içerik alanları 6 boyutta sınıflandırılmıştır. Taormina (1997) yaptığı çalışmada örgütsel sosyalleşme sürecinin eğitim, çalışma arkadaşlarının desteği, örgütü anlama ve gelecek beklentisi boyutlarından oluştuğu belirtilmiştir. Mitus'un (2006), örgütsel sosyalleşmenin duygusal bağlllık üzerindeki etkisini ölçmek üzere yaptığı çalışma sonuçlarına göre, sosyalleşme içeriğinin çalışanların duygusal bağlılıklarını etkiledikleri ortaya çıkmıştır. Ayrıca, örgütün hedefleri ve değerleri hakkında bilgi sahibi olmanın 
örgütsel bağlılığı en güçlü şekilde etkilediği sonucuna ulaşılmıştır. Afsanepurak, Hossini, Seyfari ve Nasabi (2012), tarafından örgütsel sosyalleşme ve örgütsel bağlılık düzeyleri arasındaki ilişkiyi belirlemek amacıyla yapılan çalışma sonucunda örgütsel sosyalleşme ile örgütsel bağlllık arasında anlamlı bir ilişki olduğu; örgütsel sosyalleşmenin eğitim ve gelecek beklentileri boyutları ile örgütsel bağlılık arasında daha anlamlı bir ilişki olduğu belirlenmiştir. Dolayısıyla, yukarıda bahsedilen teorik çerçeve ve ilgili çalışmalardan hareketle araştırmanın, örgütsel sosyalleşme ve örgütsel bağlılık ilişkisine yönelik hipotezler şu şekilde oluşturulmuştur:

- H: Örgütsel sosyalleşmenin iş eğitimi boyutunun duygusal bağhllı üzerinde pozitifbir etkisi vardir.

- H10: Örgütsel sosyalleşmenin örgütü anlama boyutunun duygusal bağhllk üzerinde pozitif bir etkisi vardır.

- H11: Örgütsel sosyalleşmenin çalışma arkadaşlarmmn desteği boyutunun duygusal bağlllık üzerinde pozitifbir etkisi vardır.

- H12: Örgütsel sosyalleşmenin geleceğe ilişkin beklentiler boyutunun duygusal bağhllık üzerinde pozitifbir etkisi vardır.

- H13: Örgütsel sosyalleşmenin iş eğitimi boyutunun devam bağhllh̆̆ üzerinde pozitifbir etkisi vardir.

- H14: Örgütsel sosyalleşmenin örgütü anlama boyutunun devam bağhllğ̆ üzerinde pozitif bir etkisi vardir.

- H15: Örgütsel sosyalleşmenin çalışma arkadaşlarmmn desteği boyutunun devam bağllı̆̆̆ üzerinde pozitif bir etkisi vardır.

- H16: Örgütsel sosyalleşmenin geleceğe ilişkin beklentiler boyutunun devam bağlnh̆̆ğ üzerinde pozitif bir etkisi vardır.

- H17: Örgütsel sosyalleşmenin iş eğitimi boyutunun normatif bağhllık üzerinde pozitifbir etkisi vardir.

- H1s: Örgütsel sosyalleşmenin örgütü anlama boyutunun normatif bağhllk üzerinde pozitif bir etkisi vardir.

- H19: Örgütsel sosyalleşmenin çalışma arkadaşlarmın desteği boyutunun normatifbağhllık üzerinde pozitif bir etkisi vardır.

- Hzo: Örgütsel sosyalleşmenin geleceğe ilişkin beklentiler boyutunun normatif bağhllı üzerinde pozitifbir etkisi vardır.

Psikolojik sözleşme, örgütsel bağlllığı etkileyen önemli faktörlerdendir. Çalışanların psikolojik sözleşmelerindeki beklentilerin işverenlerce ne kadar karşılandığına yönelik algısı, örgüte olan bağlılıklarını etkileyecektir. Pek çok 
araştırmada da psikolojik sözleşme ile örgütsel bağlllık arasındaki ilişki, pozitif ve yüksek düzeyde tespit edilmiştir. Coyle-Shapiro ve Kessler (2003) yapmış oldukları çalışmada psikolojik sözleşme ile örgütsel bağlılık ve örgütsel vatandaşlık arasındaki ilişkiyi incelemişlerdir. Araştırma sonuçlarına göre, psikolojik sözleşmede verilen sözlerin yerine getirilmesiyle örgütsel bağlllık arasında pozitif bir ilişki olduğu fakat örgütsel bağlllı̆̆ın en güçlü yordayıcısının, algılanan örgütsel destek olduğu ortaya çımıştır. Ayrıca, ilişkisel sözleşmenin yerine getirilmesinin örgütsel vatandaşlık davranışıyla pozitif ilişkili, işlemsel sözleşmenin ise negatif ilişkili olduğu tespit edilmiştir (Coyle-Shapiro ve Kessler, 2003). Agarwal (2011) yılında yaptığ 1 çalışmada psikolojik sözleşmenin ve örgütsel bağlılığın ilişkisini incelemiştir. Araştırmanın sonuçlarına göre örgütsel bağlıllğın örgütte kalma isteği ve değer bağlıllğı boyutlarının anlamlı ve pozitif şekilde psikolojik sözleşme ile ilişkili olduğu ortaya çıkmıştır. Sunulan bu teorik çerçeve ve bulgulardan hareketle araştırmanın, psikolojik sözleşme ve örgütsel bağlllık ilişkisine yönelik hipotezler şu şekilde oluşturulmuştur:

- H21: Işlemsel sözleşmenin duygusal bağlllık üzerinde negatif bir etkisi vardır.

- H22: Illişkisel sözleşmenin duygusal bağlllık üzerinde pozitif bir etkisi vardır.

- H2z: Işlemsel sözleşmenin devam bağhll̆ğ üzerinde negatif bir etkisi vardır.

- H24: Iliş̧kisel sözleşmenin devam bağhllı̆̆ üzerinde pozitif bir etkisi vardır.

- H25: Işlemsel sözleşmenin normatif bağhllı üzerinde negatif bir etkisi vardır.

- H26: Illişkisel sözleşmenin normatif bağlllk üzerinde pozitif bir etkisi vardır.[

Araştırmanın hipotezleri doğrultusunda Alanya Belediyesi'nde çalışan, araştırmaya katılan katılımcıların örgütsel sosyalleşme düzeylerinin işlemsel ve ilişkisel psikolojik sözleşmeleri üzerine etkisi; örgütsel sosyalleşme düzeylerinin örgütsel bağlılığın boyutları üzerine etkisi ve çalışanların ilişkisel ve işlemsel sözleşmelerinin örgütsel bağlllık boyutları üzerine etkisi ele alınmıştır. Araştırma nicel araştırma desenlerinden nedensel ilişki tasarımına dayanmaktadır. Bu doğrultuda araştırmanın modeli oluşturulmuştur. Örgütsel sosyalleşme, psikolojik sözleşme ve örgütsel bağlllı̆̆a ilişkin yukarıda örnekleri verilen literatür incelemesi sonucunda elde edilen bilgiler doğrultusunda Şekil 1'de yer alan araştırma modeli oluşturulmuştur. 


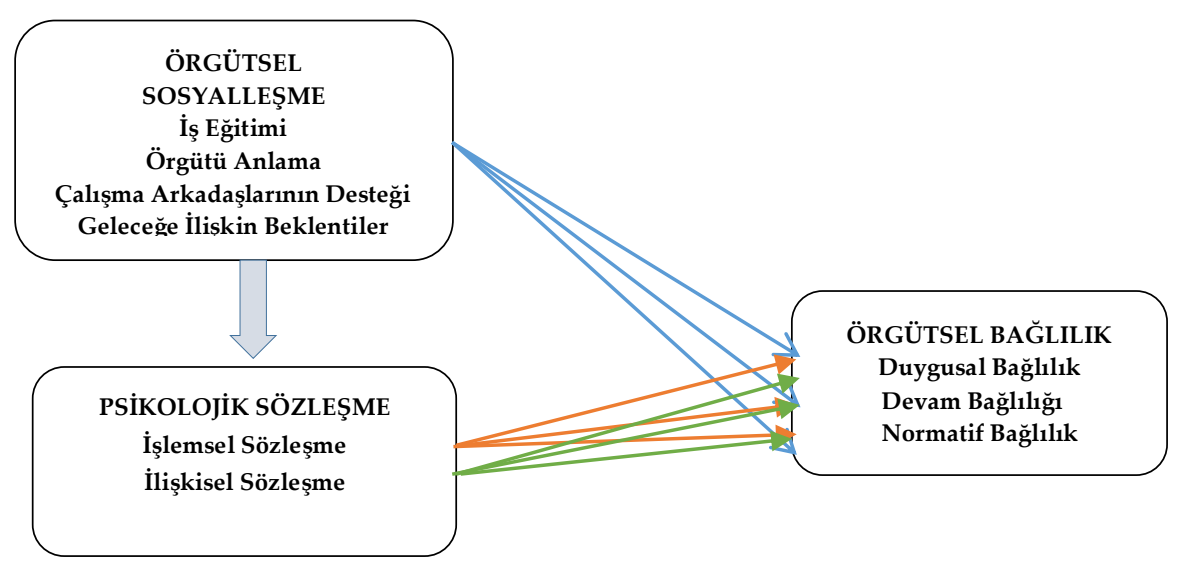

Şekil 1. Araştırmanın Modeli

\section{Yöntem}

\section{Örneklem}

$\mathrm{Bu}$ çerçevede anılan konular arasındaki ilişkileri örüntülerini tespit etmek için Alanya Belediye'sinde bir saha araştırması yapılmıştır. Araştırmanın evreni, Alanya Belediyesi'ndeki çalışanlardan oluşmaktadır. Alanya Belediyesi insan kaynakları birimi kaynaklarına göre 2016 yılı itibariyle 2600 çalışan görev yapmaktadır. Araştırmada, evrenin tümüne ulaşmak zaman ve maliyet açısından mümkün olmadığından evreni temsil edecek örneklem için "tanımlanan evrendeki her elemanın 'eşit' ve 'bağımsız' seçilme şansına sahip olması" (Coşkun, Altunışık ve Yıldırım, 2017, s.146) olarak ifade edilen basit tesadüfi örnekleme tekniği kullanılmıştır. Araştırma 2016 yılının şubat ayında, Alanya Belediyesi İnsan Kaynakları Biriminin ve Akademik Araştırmalar Merkezi'nin bilgisi dahilinde ve desteği ile yapılmıştır ve çeşitli beldelerde bulunan hizmet binaları ve şantiyeler dolaşılarak çalışanlara ulaşılmıştır. Araştırma kapsamında hazırlanan anket formları Alanya Belediyesi'nde görev yapan 400 personele dağıtılmış, 350 form değerlendirmeye dahil edilmiştir. Araştırmada veri toplama aracı olarak anket tekniğinden yararlanılmış ve belediye çalışanlarının örgütsel sosyalleşme düzeyleri, psikolojik söz- 
leşme türleri ve örgütsel bağlllık düzeylerini belirlemek amacıyla her üç konuyla ilgili daha önceden farklı araştırmacılar tarafından geliştirilmiş ölçekler kullanılmıştır.

Öncelikle cinsiyet, yaş, eğitim, medeni durum, iş deneyimi, kurumda çalışma süresi, çalışma statüsü ve yapılan işin türü hakkında 8 soru yöneltilmiştir. Örgütsel sosyalleşmeyi ölçmek amacıyla Taormina'nın (1994; 2004) geliştirdiği ölçekten yararlanılmıştır. Ölçek; beşer sorudan oluşan, iş eğitimi, örgütü anlama, iş arkadaşlarının desteği, geleceğe dönük beklentiler gibi boyutlara sahiptir. Sonraki bölümde, psikolojik sözleşmeleyi ölçmek için Millward ve Hopkins' in (1998) 17 soruluk "Psikolojik Sözleşme Ölçeği" bulunmaktadır. Yılmaz'ın (2012) yüksek lisans tezinde de yer alan bu ölçeğin ifadeleri kullanılmıştır. Son bölümde ise örgütsel bağlllı̆̆ ölçmek için Meyer, Allen ve Smith' in (1993) 18 maddelik "Örgütsel Bağlılık Ölçeği”" kullanılmıştır. Ölçeğin Türkçe uyarlaması Wasti (2000) tarafından yapılmıştır. Bu araştırmada, çalışanların örgütsel bağlllıklarının ölçmek için, $\mathrm{Al}$ (2007) tarafından hazırlanan yüksek lisans tezinde yer alan anket sorularından yararlanılmıştır. Örgütsel sosyalleşme ölçeği literatürde pek çok çalışma tarafından kullanılmıştır (Aliyev, 2014; Çerik ve Bozkurt, 2010; Çetin ve Kurban, 2016; Tetik, 2019; Yıldırım, 2014; Zonana, 2011). Psikolojik sözleşme ölçeği Çiçeklioğlu ve Taşlıyan, (2018), Demirkasımoğlu, (2012); Özler ve Ünver (2012) ve Yılmaz (2012) tarafından yapılan çalışmalarda kullanılmıştır. Örgütsel bağlılık ölçeğinden de, ilgili yabancı literatürde olduğu gibi yerli literatürde çeşitli araştırmalarda (Polat ve Uğurlu, 2009; Uyguç ve Çımrın, 2004) yararlanılmıştır.

Güvenirlik analizi sonuçlarına göre örgütsel sosyalleşme ölçeğinin genel güvenirlik düzeyi 0,93; psikolojik sözleşme ölçeğinin güvenirlik düzeyi 0,79 ve örgütsel bağlılık ölçeğinin güvenirlik düzeyi $0,85^{\prime}$ dır. 
Tablo. 1. Boyutlara İlişkin Standart Sapma, Ortalama ve Güvenirlik Analizi Sonuçları

\begin{tabular}{lccc}
\hline & s.s. & $\overline{\mathbf{x}}$ & Cronbach Alpha \\
\hline Örgütsel Sosyalleşmenin Boyutları & & & \\
\hline İş Eğitimi & 0,954 & 3,284 & .851 \\
\hline Örgütü Anlama & 0,765 & 3,776 & .812 \\
\hline Çalışma Arkadaşlarının Desteği & 0,727 & 3,829 & .793 \\
\hline Gelecek Beklentileri & 0,894 & 3,213 & .817 \\
\hline Psikolojik Sözleşmenin Boyutları & & & \\
\hline İşlemsel Sözleşme & 0,691 & 3,349 & .730 \\
\hline İlişkisel Sözleşme & 0,690 & 3,561 & .809 \\
\hline Örgütsel Bağlı̆ı̆̆ın Boyutları & & & \\
\hline Duygusal Bağlılık & 0,798 & 3,495 & .754 \\
\hline Devam Bağlı̆ı̆̆ & 0,798 & 3,475 & .784 \\
\hline Normatif Bağlılık & 0,743 & 3,444 & .748 \\
\hline
\end{tabular}

Üç ölçeğinde literatürdeki sonuçlarla benzer şekilde güvenilir sayılabilecek düzeyde olduğu görülmüştür. Boyutlara ilişkin standart sapma ve ortalamalar ile güvenirlik analizleri sonuçları Tablo 1.'de gösterilmiştir.

\section{Araştırmanın Bulguları}

\section{Demografik Bulgular}

Araştırmaya katılım gösteren çalışanların \%77,7'si erkek, \%22,3'ü kadındır. Yaş aralıklarına bakıldığında çalışanların \%30'u 20-30 yaş, \%54'ü 31-45 yaş, $\% 15,4$ 'ü ise 45 ve üzeri yaş aralığındadır. Medeni durum değişkenine ilişkin sonuçlar incelendiğinde $\% 71,7$ sinin evli, \% 26,6'sının ise bekar olduğu görülmüştür. Eğitim düzeyine bakıldığında ise \%34,6'sının ilköğretim, \%35,1'inin lise, \%29,1'inin ise üniversite mezunu olduğu sonucu çıkmıştır. İş deneyimi açısından çalışanların \% 77,7'sinin 61-450 ay arasında deneyime sahip olduğu ve çalışanların \%58'inin ise 61-450 ay arasında kurumda çalışmakta olduğu görülmüştür. Çalışma statüsü ve yaptığı işin türü açısından ise ankete katılanların \%63,4'ünün taşeron statüde olduğu; \%37,7'sinin teknik ve \%53,1'inin idari işlerde görev yaptığı bulgusuna ulaşılmıştır. Ankete katılan çalışanların çoğunluğunun erkek, 31-45 yaş aralığında, evli olduğu görülmüştür. Eğitim düzeyleri açısından ilköğretim ve lise mezunu olanların ağırlıkta olduğu söylenmekle birbirine yakın sonuçlara ulaşılmıştır. İş deneyimi açısından çalışanların ağırlıklı olarak 61-450 ay (5-37,5 yıl) arasında deneyime sahip olduğu, \%58'nin yine 61-450 ay (5-37,5 yıl) aynı kurumda çalışma deneyimine sahip olduğu ve ağırlıklı olarak ankete katılanların taşeron statüde olduğu ve idari işlerde çalıştığı görülmüştür. 


\section{Regresyon Analizine İlişkin Bulgular}

Araştırma hipotezlerini test etmek amacıyla regresyon analizleri gerçekleştirilmiştir. Tablo 2 ‘de Örgütsel Sosyalleşme Boyutlarının İşlemsel Sözleşme üzerindeki etkisine yönelik regresyon analizi sonuçları yer almaktadır. Tablo 2'de yer alan analiz sonuçlarına göre; örgütsel sosyalleşmenin alt boyutları psikolojik sözleşmenin işlemsel sözleşme boyutu üzerindeki etkisini, \%4 düzeyinde 0,001 anlamlılık ile açıklamaktadır $\left(R=0,201 / R^{2}=0,041\right)$. Örgütsel sosyalleşmenin alt boyutları incelendiğinde ise; iş eğitimi ( $(\Omega=0,024 ; p>0,05)$, örgütü anlama $(\Omega=-0,113 ; p>0,05)$, çalışma arkadaşlarının desteği $(B=0,073$; $\mathrm{p}>0,05)$ boyutlarının işlemsel sözleşme üzerinde etkisinin olmadığı, ancak geleceğe ilişkin beklenti $(\Omega=0,202 ; p<0,05)$ boyutunun, işlemsel sözleşme üzerinde anlamlı ve pozitif etkisinin olduğu ifade edilebilmektedir.

Tablo 2. Örgütsel Sosyalleşme Boyutlarnın İşlemsel Sözleşme Üzerindeki Etkisine Yönelik Regresyon Analizi Sonuçlan

\begin{tabular}{|c|c|c|c|c|c|}
\hline \multirow{2}{*}{ Model 1} & \multicolumn{5}{|c|}{ İşlemsel Sözleşme } \\
\hline & B & Std. Hata & B & $t$ & $\mathrm{p}$ \\
\hline Sabit & 2,916 & ,211 & - & 13,808 & ,000 \\
\hline İş Eğitimi & 018 & ,067 & 024 & 264 & ,792 \\
\hline Örgütü Anlama &,- 102 & 076 &,- 113 & $-1,350$ & ,178 \\
\hline Çalışma Arkadaşlarının Desteği & ,069 & 070 & , 073 & ,987 & 325 \\
\hline Geleceğe İlişkin Beklenti & ,155 & ,074 & 202 & 2,112 & ,035 \\
\hline \multicolumn{6}{|l|}{$\mathrm{R}=, 201$} \\
\hline \multicolumn{6}{|l|}{$\mathrm{R}^{2}=, 041$} \\
\hline \multicolumn{6}{|l|}{$F=3,606$} \\
\hline \multicolumn{6}{|l|}{ Durbin-Watson $=1,793$} \\
\hline $\mathrm{p}=0,007$ & & & & & \\
\hline
\end{tabular}

Dolayısıyla örgütsel sosyalleşme boyutlarının işlemsel sözleşme üzerinde negatif bir etkisinin olacağına ilişkin oluşturulan $H_{1}, H_{2}$ ve $H_{3}$ ve $H_{4}$ hipotezleri reddedilmiştir. Tablo 3'te örgütsel sosyalleşme boyutlarının ilişkisel psikolojik sözleşme üzerindeki etkisine yönelik regresyon analizi sonucuna yer verilmiştir.

Tablo 3. Örgütsel Sosyalleşme Boyutlarnm İlişkisel Psikolojik Sözleşme Üzerindeki Etkisine Yönelik Regresyon Analizi Sonuçlan

\begin{tabular}{llllll}
\hline \multirow{2}{*}{ Model 1} & \multicolumn{3}{l}{ Ilişkisel Sözleşme } & & \\
\cline { 2 - 7 } & $\mathbf{B}$ & Std. Hata & $\mathbf{B}$ & $\mathbf{t}$ & $\mathbf{p}$ \\
\hline Sabit & $\mathbf{1 , 4 3 7}$ & $\mathbf{1 3 9}$ & - & $\mathbf{1 0 , 3 4 9}$ & $\mathbf{0 , 0 0 0}$ \\
\hline İş Eğitimi &, 013 &, 044 &, 018 &, 301 &, 764 \\
\hline
\end{tabular}




\begin{tabular}{llllll}
\hline Örgütü Anlama &, 337 &, 050 &, 374 & 6,729 &, 000 \\
\hline Çalışma Arkadaşlarının Desteği &,- 127 &, 047 &,- 133 & $-2,727$ &, 007 \\
\hline Geleceğe İlişkin Beklenti &, 404 &, 049 &, 524 & 8,285 &, 000 \\
\hline $\mathbf{R}=, 761$ & & & & & \\
\hline $\mathbf{R}=, 580$ & & & & & \\
\hline $\mathrm{F}=117,973$ & & & & & \\
\hline Durbin-Watson $=\mathbf{1 , 8 1 4}$ & & & & & \\
\hline $\mathrm{p}=, \mathbf{0 0 0}$ & &
\end{tabular}

Tablo 3'de yer alan analiz sonuçlarına göre, örgütsel sosyalleşme alt boyutlarının psikolojik sözleşmenin ilişkisel sözleşme boyutu üzerindeki etkisi ise, \%58 düzeyinde 0,001 anlamlılık ile açıklanabilmektedir $\left(R=0,761 / R^{2}=\right.$ $0,580)$. Örgütsel sosyalleşmenin alt boyutları incelendiğinde ise; örgütü anlama $(\Omega=0,374 ; p<0,05)$ ve geleceğe ilişkin beklenti $(\Omega=0,524 ; \mathrm{p}<0,05)$ boyutlarının ilişkisel sözleşme üzerinde anlamlı ve pozitif bir etkisinin olduğu; çalışma arkadaşlarının desteği $(\Re=-0,133 ; p<0,05)$ boyutunun ilişkisel sözleşme üzerinde anlamlı fakat negatif etkisinin olduğu görülmektedir. Ancak iş eğitimi boyutunun $(\Re=0,018 ; \mathrm{p}>0,05)$, ilişkisel sözleşme üzerinde anlamlı bir etkisinin olmadığı görülmektedir. Ulaşılan bu sonuçlar doğrultusunda $H_{5}$ ve $H_{7}$ reddedilmiş; $H_{6}$ ve $H_{8}$ kabul edilmiştir. Tablo 4 'te örgütsel sosyalleşme boyutlarının duygusal bağlılık üzerindeki etkisine yönelik regresyon analizi sonucuna yer verilmiştir.

Tablo 4. Örgütsel Sosyalleşme Boyutlarnın Duygusal Bağlllkk Boyutu Üzerindeki Etkisine Yönelik Regresyon Analizi Sonucu

\begin{tabular}{|c|c|c|c|c|c|}
\hline \multirow{2}{*}{ Model 1} & \multicolumn{5}{|c|}{ Duygusal Bağlılık } \\
\hline & B & Std. Hata & B & $\mathbf{t}$ & $\mathbf{p}$ \\
\hline Sabit & 1,445 & 207 & - & 6,988 & 0,000 \\
\hline İş Eğitimi &,- 012 & ,066 &,- 015 &,- 188 & 851 \\
\hline Örgütü Anlama & ,608 & 074 & 5,583 & 8,163 & ,000 \\
\hline Çalışma Arkadaşlarının Desteği &,- 071 & ,069 &,- 064 & $-1,028$ & 305 \\
\hline Geleceğe İlişkin Beklenti &, 021 & 073 &, 024 & 290 & ,772 \\
\hline \multicolumn{6}{|l|}{$\mathrm{R}=, 550$} \\
\hline \multicolumn{6}{|l|}{$R^{2}=, 302$} \\
\hline \multicolumn{6}{|l|}{$F=37,012$} \\
\hline \multicolumn{6}{|l|}{ Durbin-Watson $=1,663$} \\
\hline $\mathrm{p}=, 000$ & & & & & \\
\hline
\end{tabular}


Tablo 4'de yer alan veriler değerlendirildiğinde, bu modelde örgütsel sosyalleşme alt boyutlarının örgütsel bağlllığın duygusal bağlllık boyutu üzerindeki etkisinin, \%30 düzeyinde 0,001 anlamlılık ile açıklandığı görülmektedir $\left(R=0,550 / R^{2}=0,302\right)$. Örgütsel sosyalleşmenin boyutları incelendiğinde ise; örgütü anlama $(\Omega=0,583 ; p<0,05)$ boyutunun duygusal bağlllı üzerinde anlamlı ve pozitif etkisinin olduğu görülmektedir. İş eğitimi $(ß=-0,015 ; p>0,05)$ çalışma arkadaşlarının desteği $(\Omega=-0,064 ; p>0,05)$ ve geleceğe ilişkin beklenti $(\Re=0,024 ; p>0,05)$ boyutlarının duygusal bağlllık üzerinde anlamlı etkisinin olmadığı görülmektedir. Dolayısıyla, $H_{9}, H_{11}$ ve $H_{12}$ desteklenmezken, $H_{10}$ kabul edilmiştir. Tablo 5 'te örgütsel sosyalleşme boyutlarının devam bağllı̆̆ı boyutu üzerindeki etkisine yönelik regresyon analizi sonucuna yer verilmiştir.

Tablo 5. Örgütsel Sosyalleşme Boyutlarının Devam Bağlılı̆̆ı Boyutu Üzerindeki Etkisine Yönelik Regresyon Analizi Sonucu

\begin{tabular}{|c|c|c|c|c|c|}
\hline \multirow{2}{*}{ Model 1} & \multicolumn{5}{|c|}{ Devam Bağlılığ1 } \\
\hline & B & Std. Hata & B & $t$ & $\mathrm{p}$ \\
\hline Sabit & 1,492 & 209 & - & 7,143 & 0,000 \\
\hline İş Eğitimi & 176 & ,067 & ,211 & 2,646 & ,009 \\
\hline Örgütü Anlama & 357 & 075 & ,342 & 4,747 & ,000 \\
\hline Çalışma Arkadaşlarının Desteği &,- 019 & 069 &,- 018 &,- 278 & 7,781 \\
\hline Geleceğe İlişkin Beklenti & 041 & 073 & ,046 &, 563 & 574 \\
\hline \multicolumn{6}{|l|}{$\mathrm{R}=, 536$} \\
\hline \multicolumn{6}{|l|}{$\mathrm{R}^{2}=, 287$} \\
\hline \multicolumn{6}{|l|}{$F=34,592$} \\
\hline \multicolumn{6}{|l|}{ Durbin-Watson $=1,732$} \\
\hline $\mathrm{p}=, 000$ & & & & & \\
\hline
\end{tabular}

Tablo 5'de yer alan veriler değerlendirildiğinde, bu modelde örgütsel sosyalleşme alt boyutlarının örgütsel bağlılığın devamlılık bağlılığı boyutu üzerindeki etkisinin, \%28 düzeyinde 0,001 anlamlılık ile açıkladığ1 görülmekte$\operatorname{dir}\left(R=0,536 / R^{2}=0,287\right)$. Örgütsel sosyalleşmenin boyutları incelendiğinde ise, iş eğitimi $(\Omega=0,211 ; p<0,05)$ ve örgütü anlama $(\Omega=0,342 ; p<0,05)$ boyutlarının devam bağlılığı üzerinde anlamlı ve pozitif bir etkisinin olduğu görülmüştür. Ancak çalışma arkadaşlarının desteği $(\Omega=-0,018 ; p>0,05)$ ve geleceğe ilişkin beklenti boyutlarının ise $(\Omega=0,046 ; p>0,05)$ devam bağlılığ $\ddot{1}$ üzerinde anlamlı bir etkisinin olmadığı görülmüştür. Ulaşılan bu sonuçlar doğrultusunda $H_{13}$ ve $H_{14}$ kabul edilirken; $H_{15}$ ve $H_{16}$ reddedilmiştir. Tablo 6 'da örgütsel sosyalleşme boyutlarının normatif bağlılık üzerindeki etkisine yönelik regresyon analizi sonucuna yer verilmiştir. 
Tablo 6. Örgütsel Sosyalleşme Boyutlarnın Normatif Bağlılık Boyutu Üzerindeki Etkisine Yönelik Regresyon Analizi Sonucu

\begin{tabular}{|c|c|c|c|c|c|}
\hline \multirow{2}{*}{ Model 1} & \multicolumn{5}{|c|}{ Normatif Bağlılık } \\
\hline & B & Std. Hata & $\mathbf{B}$ & $t$ & $p$ \\
\hline Sabit & 1,367 & 190 & - & 7,179 & 0,000 \\
\hline İş Eğitimi & ,068 & ,061 & ,087 & 1,116 & 265 \\
\hline Örgütü Anlama & 309 & 069 & ,318 & 4,511 & 000 \\
\hline Çalışma Arkadaşlarının Desteği & 071 & ,063 & ,069 & 1,123 & 262 \\
\hline Geleceğe İlişkin Beklenti & 130 & 067 & ,156 & 1,937 & 054 \\
\hline \multicolumn{6}{|l|}{$\mathrm{R}=563$} \\
\hline \multicolumn{6}{|l|}{$\mathrm{R}^{2}=, 317$} \\
\hline \multicolumn{6}{|l|}{$\mathrm{F}=39,807$} \\
\hline \multicolumn{6}{|l|}{ Durbin-Watson $=1,977$} \\
\hline $\mathrm{p}=0,000$ & & & & & \\
\hline
\end{tabular}

Tablo 6 'da yer alan veriler değerlendirildiğinde, örgütsel sosyalleşme alt boyutlarının örgütsel bağllı̆̆ın normatif bağlllık boyutu üzerindeki etkisini \%31 düzeyinde 0,001 anlamlılık ile açıkladığı görülmektedir. Örgütsel sosyalleşmenin alt boyutları incelendiğinde ise; iş eğitimi $(\Omega=0,087 ; p>0,05)$, çalışma arkadaşlarının desteği $(\Omega=0,069 ; p>0,05)$ ve geleceğe ilişkin beklenti $(\Omega=0,156$; $p>0,05)$ boyutlarının normatif bağlılık üzerinde anlamlı etkisinin olmadığı görülmüştür. Ancak, örgütü anlama $(\beta=0,069 ; p<0,05)$ boyutunun normatif bağlllık üzerinde anlamlı ve pozitif etkisinin olduğu görülmüştür. Ulaşılan bu sonuçlar doğrultusunda $\mathrm{H}_{17}, \mathrm{H}_{19}$ ve $\mathrm{H}_{20}$ desteklenmezken, $\mathrm{H}_{18}$ kabul edilmiştir. Tablo 7'de işlemsel ve ilişkisel sözleşmenin duygusal bağlllık boyutu üzerindeki etkisine yönelik regresyon analizi sonucuna yer almaktadır.

Tablo 7. Psikolojik Sözleşme Boyutlarının Duygusal Bağlılık Boyutu Üzerindeki Etkisine Yönelik Regresyon Analizi Sonucu

\begin{tabular}{|c|c|c|c|c|c|}
\hline \multirow{2}{*}{ Model 1} & \multicolumn{5}{|c|}{ Duygusal Bağlılık } \\
\hline & B & Std. Hata & B & $t$ & $\mathrm{p}$ \\
\hline Sabit & 2,379 & 219 & - & 10,857 & 0,000 \\
\hline İşlemsel Sözleşme &,- 400 & ,051 &,- 347 & $-7,890$ & ,000 \\
\hline İlişkisel Sözleşme & 689 & 051 &, 595 & 13,543 &, 000 \\
\hline \multicolumn{6}{|l|}{$\mathrm{R}=, 612$} \\
\hline \multicolumn{6}{|l|}{$\mathrm{R}^{2}=, 375$} \\
\hline \multicolumn{6}{|l|}{$F=103,014$} \\
\hline \multicolumn{6}{|l|}{ Durbin-Watson=1,759 } \\
\hline $\mathrm{p}=, 000$ & & & & & \\
\hline
\end{tabular}


Tablo 7' de işlemsel ve ilişkisel sözleşmenin, örgütsel bağlllı̆̆ın duygusal bağlılık boyutu üzerindeki etkisini belirlemek amacıyla gerçekleştirilen regresyon analizi sonuçlarına göre, model işlemsel ve ilişkisel psikolojik sözleşmenin, duygusal bağlılık üzerindeki etkisini \%37 düzeyinde 0,001 anlamlılık ile açıklamaktadır $\left(R=0,612 / R^{2}=0,375\right)$. İşlemsel sözleşmenin $(\Omega=-0,347$; $\mathrm{p}<0,05)$ duygusal bağllık üzerinde anlamlı ve negatif etkisinin olduğu; ilişkisel sözleşmenin $(§=0,595 ; \mathrm{p}<0,05)$, duygusal bağlllık boyutu üzerinde anlamlı ve pozitif etkisinin olduğu görülmektedir. Ulaşılan bu sonuçlar doğrultusunda, $H_{21}$ ve $H_{22}$ kabul edilmiştir. Tablo 8 'de işlemsel ve ilişkisel sözleşmenin devam bağlılığı boyutu üzerindeki etkisine yönelik regresyon analizi sonucuna yer verilmiştir.

Tablo 8. Psikolojik Sözleşme Boyutlarnın Devam Bağhllğı Boyutu Üzerindeki Etkisine Yönelik Regresyon Analizi Sonucu

\begin{tabular}{|c|c|c|c|c|c|}
\hline \multirow{2}{*}{ Model 1} & \multicolumn{5}{|c|}{ Devam Bağlılığı } \\
\hline & B & Std. Hata & $B$ & $t$ & p \\
\hline Sabit & 0,912 & ,229 & - & 3,982 & 0,000 \\
\hline İşlemsel Sözleşme & 108 & ,053 &,- 093 & 2,025 & ,044 \\
\hline İlişkisel Sözleşme & ,618 & 053 &, 533 & 11,605 & ,000 \\
\hline \multicolumn{6}{|l|}{$\mathrm{R}=564$} \\
\hline \multicolumn{6}{|l|}{$R^{2}=, 318$} \\
\hline \multicolumn{6}{|l|}{$\mathrm{F}=80,197$} \\
\hline \multicolumn{6}{|l|}{ Durbin-Watson=1,799 } \\
\hline$p=, 000$ & & & & & \\
\hline
\end{tabular}

Tablo 8'de işlemsel ve ilişkisel sözleşmenin, örgütsel bağlllı̆̆ın devam bağlılığı boyutu üzerindeki etkisini belirlemek amaciyla gerçekleştirilen regresyon analizi sonuçlarına göre; model, işlemsel ve ilişkisel sözleşmenin örgütsel bağllı̆̆ın devamlılık bağlılı̆̆ boyutu üzerindeki etkisini \%31,8 düzeyinde 0,001 anlamlılık ile açıklamaktadır $\left(R=, 564 / R^{2}=0,318\right)$. İşlemsel sözleşmenin $(\Omega=0,093 ; p<0,05)$ devam bağlılığı üzerinde anlamlı ve negatif etkisinin olduğu; ilişkisel sözleşmenin $(\Omega=0,533 ; p<0,05)$ devam bağlllı̆̆ üzerinde anlamlı ve pozitif etkisinin olduğu görülmektedir. Bu sonuçlar doğrultusunda $H_{23}$ ve $H_{24}$ kabul edilmiştir. Tablo 9'da işlemsel ve ilişkisel sözleşmenin normatif bağllık boyutu üzerindeki etkisine yönelik regresyon analizi sonucu yer almaktadır. 
Tablo 9. Psikolojik Sözleşme Boyutlarının Normatif Bağhlık Boyutu Üzerindeki Etkisine Yönelik Regresyon Analizi Sonucu

\begin{tabular}{|c|c|c|c|c|c|}
\hline \multirow{2}{*}{ Model 1} & \multicolumn{5}{|c|}{ Normatif Bağlılık } \\
\hline & B & Std. Hata & B & $t$ & $\mathrm{p}$ \\
\hline Sabit & 1,166 & 208 & - & 5,599 & 0,000 \\
\hline İşlemsel Sözleşme & ,020 & ,049 &,- 019 & 417 & 677 \\
\hline İlişkisel Sözleşme & 621 & ,048 & ,579 & 12,828 & ,000 \\
\hline \multicolumn{6}{|l|}{$\mathrm{R}=584$} \\
\hline \multicolumn{6}{|l|}{$\mathbf{R}^{2}=, 342$} \\
\hline \multicolumn{6}{|l|}{$\mathrm{F}=89,207$} \\
\hline \multicolumn{6}{|l|}{ Durbin-Watson=1,945 } \\
\hline$p=000$ & & & & & \\
\hline
\end{tabular}

Tablo 9'da işlemsel ve ilişkisel sözleşmenin, örgütsel bağllliğın normatif bağlllık boyutu üzerindeki etkisini belirlemek amacıyla gerçekleştirilen regresyon analizi sonuçlarına göre; model, işlemsel ve ilişkisel sözleşmenin örgütsel bağllı̆̆ın normatif bağlılık boyutu üzerindeki etkisini \%34 düzeyinde 0,001 anlamlılık ile açıklamaktadır $\left(\mathrm{R}=0,584 / \mathrm{R}^{2}=, 342\right)$. İşlemsel sözleşmenin $(ß=-, 019 ; p>0,05)$ normatif bağlllık üzerinde bir etkisi bulunmamaktadır. İlişkisel sözleşmenin $(\Re=0,579 ; p<0,05)$ ise, normatif bağlllık üzerinde anlamlı ve pozitif etkisi bulunmaktadır. Ulaşılan sonuçlar doğrultusunda $H_{25}$ desteklenmezken, $\mathrm{H}_{26}$ kabul edilmiştir.

\section{Tartışma}

Bu araştırmada çalışanların örgütsel sosyalleşmelerinin ve psikolojik sözleşmelerinin örgütsel bağlılıkları üzerindeki etkisi incelenmiştir. Ayrıca örgütsel sosyalleşmenin psikolojik sözleşme türleri üzerindeki etkisi de çalışma kapsamında araştırılmıştır. Yapılan çoklu regresyon analizinde ilk olarak, örgütsel sosyalleşme boyutlarının işlemsel sözleşme üzerindeki etkisi incelenmiştir. Bu analiz sonuçları incelendiğinde iş eğitimi, örgütü anlama, çalışma arkadaşlarının desteği boyutlarının işlemsel sözleşme üzerinde etkisinin olmadığı; ancak geleceğe ilişkin beklenti boyutunun, işlemsel sözleşme üzerinde anlamlı ve pozitif etkisinin olduğu sonucuna ulaşılmıştır. Gelecek beklentileri, örgüt tarafından tanınma, örgütte tatmin edici bir kariyere ulaşma şeklinde manevi unsurlarla ilişki olabildiği gibi örgüt tarafından verilen ödüller, promosyon, ikramiye gibi (Taormina ve Law, 2000) maddî unsurlarla da ilişkilidir. Bunlar çalışanların işlemsel sözleşmesini oluşturan unsurlardır. Eğer araştırmaya katılan çalışanların geleceğe ilişkin beklentileri daha maddî 
ödüllerden oluşuyorsa işlemsel sözleşmeleri pozitif yönde etkilenecektir. Örgütsel sosyalleşme boyutlarının ilişkisel sözleşme üzerindeki etkisini ölçmeye yönelik yapılan regresyon analizi sonuçlarına göre örgütsel sosyalleşmenin alt boyutları incelendiğinde; örgütü anlama ve geleceğe ilişkin beklenti boyutlarının ilişkisel sözleşme üzerinde anlamlı ve pozitif bir etkisinin olduğu; çalışma arkadaşlarının desteği boyutunun ilişkisel sözleşme üzerinde anlamlı fakat negatif etkisinin olduğu görülmektedir. Ancak iş eğitimi boyutunun, iliş̧kisel sözleşme üzerinde anlamlı bir etkisinin olmadı̆̆ görülmektedir. Çalışma arkadaşlarının desteği boyutunun ilişkisel sözleşmeyi anlamlı ve negatif etkilediği yani katılımcıların çalışma arkadaşlarından destek aldıkça ve iletişim kurdukça, kuruma karşı ilişkisel sözleşmesinin zayıfladığı sonucuna ulaşılmıştır. Frekans analizlerine göre yani katılımcıların yarısından fazlasının 5 yıldan uzun bir süredir kurumda olduğu sonucuna ulaşılmıştır. Bu sonuca göre, uzun yıllardır bu kurumda çalışanların kurumla ilgili ilişkisel sözleşmeleri çok daha netleşmiş, başlangıçtaki beklentileri değişmiş olabileceği için bu çalışanların tavsiyelerinin, özellikle onlara kıyasla daha kısa süredir kurumda çalışanların ilişkisel sözleşmelerini etkilemesi söz konusudur. Bu yüzden, çalışma arkadaşlarının desteği ve ilişkisel sözleşme arasında negatif bir ilişkinin söz konusu olması mümkündür. Fakat analiz sonuçlarına göre örgütü anlama ve gelecek beklentisinin ilişkisel sözleşmeyi pozitif etkilediği sonucuna da ulaşılmıştır. İlişkisel sözleşmeler, destek, bağlılık gibi unsurlara dayanan daha uzun dönemli sözleşmelerdir. Dolayısıyla oluşabilmesi için zaman gerekir. Bu zaman içerisinde örgütün amaç ve değerlerini ve örgütün kendisine verebileceklerini daha iyi anlayan bireylerin örgütle karşılıklı özellikle duygusal bağlılık oluşturabilecek bir ilişkisel sözleşme oluşturmaları beklenir.

İkinci olarak, örgütsel sosyalleşme alt boyutlarının örgütsel bağlllık boyutları üzerine etkisini ölçmeye yönelik gerçekleştirilen regresyon analizi sonuçlarına göre, örgütü anlama boyutunun duygusal bağlllık üzerinde anlamlı ve pozitif etkisinin olduğu görülmektedir. İş eğitimi, çalışma arkadaşlarının desteği ve geleceğe ilişkin beklenti boyutlarının duygusal bağlllık üzerinde anlamlı etkisinin olmadığı sonucuna ulaşılmıştır. Bu sonuçlara göre örgütü daha iyi anlayan, örgütün amaç ve hedeflerini benimseyen çalışanların örgüte daha fazla duygusal olarak bağlandıkları ortaya çıkmıştır. Taormina (1997) örgütsel sosyalleşmenin boyutlarını açıkladığı çalışmasında örgütü anlama boyutunun duygusal ve normatif bağlllıkla ile yakından ilişkili olduğu 
sonucuna ulaşmıştır. Mitus (2006) tarafından örgütsel sosyalleşmenin duygusal bağlllık üzerindeki etkisini ölçmek amacıyla yapılan çalışmada, sosyalleşme içeriğinin çalışanların duygusal bağlllıklarını etkilediği sonucuna ulaşılmıştır. Manuti vd. (2016) yapmış oldukları çalışmada etkili bir psikolojik sözleşmenin oluşturulması ve örgütsel sosyalleşme sürecinin başarısı arasındaki ilişkiyi incelemişlerdir. Çağrı merkezi çalışanları ile yürütülen alan araştırmasında çalışanlara örgütsel sosyalleşme, psikolojik sözleşme, iş tatmini ve örgütsel bağlılık sorularından oluşan bir anket uygulanmıştır. Yapılan hiyerarşik regresyon analizi sonucunda örgütsel sosyalleşmenin duygusal bağlllığın önemli bir belirleyicisi olduğu, ilişkisel sözleşmenin de duygusal bağl1lık ile önemli ölçüde ilişkili olduğu belirlenmiştir. Yapılan bu çalışmalar örgütsel sosyalleşmenin duygusal bağlllı̆̆ etkilediğine dair sonuçları destekler niteliktedir.

Örgütsel sosyalleşmenin, iş eğitimi ve örgütü anlama boyutlarının devam bağlllığı üzerinde anlamlı ve pozitif bir etkisinin olduğu görülmüştür. Ancak çalışma arkadaşlarının desteği ve geleceğe ilişkin beklenti boyutlarının ise devam bağlılığı üzerinde anlamlı bir etkisinin olmadığı sonucuna ulaşılmıştır. Devam bağlılığı çalışanın örgüte yaptıkları yatırımlarla ilişkili bir bağllıktır. İş eğitimi sırasında ve örgütü anlamak amacıyla çalışan bir çaba sarf etmektedir. İşinden ayrılırsa harcadığı bu çabanın boşa gitmesi söz konusudur. Bu araştırmada da katılımcıların böyle bir yaklaşım içerisinde olabileceği ve örgütsel sosyalleşmenin iş eğitimi ve örgütü anlama boyutlarının devam bağl1lıkları konusunda daha fazla etkili olabileceği düşünülebilir.

Örgütsel sosyalleşmenin boyutlarının normatif bağlılık üzerindeki etkisini ölçmeye yönelik regresyon analizi sonuçlarına incelendiğinde ise; iş eğitimi çalışma arkadaşlarının desteği ve geleceğe ilişkin beklenti boyutlarının normatif bağlılık üzerinde anlamlı etkisinin olmadığı görülmüştür. Ancak, örgütü anlama boyutunun normatif bağlllık üzerinde anlamlı ve pozitif etkisinin olduğu sonucuna ulaşılmıştır. Normatif bağllılık, genel olarak çalışanların örgüte bir vefa borcu olduğunu düşünerek örgütte kalmaya devam etmesidir. Bu noktada örgütün hedeflerini ve değerlerini anlayan, kendisine yap1lan yatırımların farkında olan bir çalışanın örgüte karşı normatif bağlılık geliştirmesi mümkün olabilecektir. Örgütsel sosyalleşmenin örgütsel bağl1lı̆̆1 etkilediğine dair sonuçlar, literatürde yapılmış çalışmalarla da örtüşmektedir (Afsanepurak vd., 2012; Özçelik, 2008; Ulukapı Yılmaz ve Yılmaz, 2016). 
Son olarak, psikolojik sözleşme türlerinden işlemsel ve ilişkisel sözleşmenin örgütsel bağlılık boyutları üzerindeki etkisine yönelik regresyon analizi sonuçlarına yer verilmiştir. İşlemsel ve ilişkisel sözleşmenin, örgütsel bağl1l1ğın duygusal bağll1ık boyutu üzerindeki etkisini belirlemek amaciyla gerçekleştirilen regresyon analizi sonuçlarına göre; işlemsel sözleşmenin duygusal bağlllık üzerinde anlamlı ve negatif etkisinin olduğu; ilişkisel sözleşmenin duygusal bağlllık boyutu üzerinde anlamlı ve pozitif etkisinin olduğu görülmektedir. İşlemsel sözleşme manevi unsurlardan ziyade maddi unsurlarla ilişkilidir. İşlemsel sözleşmeye yönelik beklentiler arttıkça çalışanların kuruma karşı duygusal olarak bağlılık hissetmelerinde azalma olması mümkündür. İlişkisel sözleşme ise daha çok kuruma yönelik manevi beklentilerle ilişkilidir. Bu yüzden ilişkisel sözleşme ve duygusal bağlılık arasında anlamlı ve pozitif bir ilişki olması söz konusudur. İşlemsel ve ilişkisel sözleşmenin örgütsel bağlılığın devamlılık bağlllı̆̆ boyutu üzerindeki etkisine yönelik regresyon sonuçlarına göre işlemsel sözleşmenin devam bağl1lı̆̆ üzerinde anlamlı ve negatif etkisinin olduğu; ilişkisel sözleşmenin devam bağlılığ rinde anlamlı ve pozitif etkisinin olduğu görülmektedir. İşlemsel ve ilişkisel sözleşmenin örgütsel bağlllı̆̆ın normatif bağlllık boyutu üzerindeki etkisine yönelik regresyon analizi sonuçlarına göre işlemsel sözleşmenin normatif bağllılı üzerinde bir etkisi bulunmamaktadır. İlişkisel sözleşmenin ise, normatif bağlllık üzerinde anlamlı ve pozitif etkisi bulunmaktadır. Psikolojik sözleşmenin örgütsel bağl1lı̆̆ı alt boyutlarıyla ya da bütün halinde etkilediği literatürdeki pek çok çalışmada görülmektedir (Agarwal, 2011; Coyle-Shapiro ve Kessler, 2003; Demiral, 2008; Hassan, Abdul-Rahman ve Abdul Basit, 2017; Karcığlu ve Türker, 2010; Macit ve Ekim, 2020; Özgen Mimaroğlu ve Özgen, 2010; Tsui, vd., 2013). Bu araştırma sonucunun literatürdeki ilgili çalışmalarla da örtüştüğü tespit edilmiştir. Agarwal (2011), örgütsel bağlllık ve psikolojik sözleşme ilişkisine yönelik yaptığı çalışmada psikolojik sözleşmenin örgütsel bağl1lık üzerinde etkisi olduğunu belirtmiştir. Tsui vd. (2013) psikolojik sözleşme ve örgütsel bağlılık ilişkisini incelemek amacıyla otel çalışanlarına yönelik yaptıkları araştırmanın sonuçlarına göre psikolojik sözleşmenin örgütsel bağlılığı etkilediği ortaya çıkmıştır. Macit ve Ekim (2020) sağlık çalışanlarına yönelik yaptıkları araştırmada, sağlık çalışanlarının psikolojik sözleşme konusundaki algılarının örgütsel bağlılıklarını pozitif yönlü etkilediği sonucuna ulaşmışlardır. 


\section{Sonuç ve Öneriler}

Bu araştırmada çalışanların örgütsel sosyalleşmelerinin ve işe başlarken oluşturdukları psikolojik sözleşmelerinin örgütsel bağlılıkları üzerindeki etkisi incelenmiştir. Ayrıca örgütsel sosyalleşmenin psikolojik sözleşme boyutları üzerindeki etkisi de çalışma kapsamında araştırılmıştır. Bu çalışmanın amacı, Alanya Belediyesi'nde çalışan personelin örgütsel sosyalleşmeleri, psikolojik sözleşmeleri ve örgütsel bağlılıkları arasındaki yordayıcı ilişkileri tespit etmektir. Bu amaç doğrultusunda nicel araştırma yöntemi tercih edilmiş, Alanya Belediyesi'nde alan araştırması yapılmıştır. Belediye personeline uygulanan bu çalışmada, örgütsel sosyalleşmenin ilişkisel sözleşme üzerinde etkisi olduğu; örgütsel sosyalleşmenin örgütsel bağlllık üzerinde etkisi olduğu sonucuna ulaşılmıştır. Ayrıca psikolojik sözleşme boyutlarının da örgütsel bağlılık üzerinde etkisi olduğu tespit edilmiştir.

Örgütsel sosyalleşme, psikolojik sözleşme ve örgütsel bağlllık arasındaki ilişkiyi incelemeye yönelik az sayıda çalışma olmasından dolayı, bu çalışmanın literatüre katkı sağlaması beklenmektedir. Bu çalışma kamu sektöründe bir kuruma uygulanmıştır. Konunun daha net anlaşılabilmesi için daha geniş bir örnekleme ve farklı sektörlere uygulanması gerekmektedir. Yapılan bu araştırmadan hareketle doğrudan veya dolaylı olarak birtakım öneriler getirilebilir. Araştırma sonuçları doğrultusunda verilebilecek öneriler ise şu şekildedir:

Örgütlerin çalışanların örgütsel sosyalleşme sürecine önem vermeleri gerekmektedir. Özellikle bu süreçte örgütlerin amaç ve değerlerini, hedeflerini, çalışandan beklentilerini doğru bir şekilde işgörenlere aktarmaları çalışanların psikolojik sözleşmesindeki beklentilerinin daha gerçekçi beklentilere dönüşmesini sağlar. Örgütsel sosyalleşme sürecinde çalışma arkadaşları desteğinin ilişkisel sözleşmeye olumlu etkisinin olduğu sonucuna ulaşılmıştır. Çalışanların arkadaşlarından işiyle ilgili destek alması her ne kadar yardım edecek kişilere bağ lı olmakla birlikte örgüt kültürünün etkisi de büyük rol oynar. Örgütlerde, çalışanlar arasında yardımlaşmayı sağlayan, iletişim açı olduğu bir ortamın oluşması oldukça önemlidir.

Örgütlerin işgörenlerle uzun yıllar çalışabilmesi onların psikolojik sözleşmelerindeki beklentilerinin karşılanmasıyla yakından ilişkilidir. Çalışanlar bu beklentilerinin büyük bir kısmını kendilerine vaat edilenler üzerinden oluşturmaktadır. Bu nedenle örgütlerin çalışanlara verdikleri sözlerde çok 
dikkatli davranmaları ve tutamayacakları sözlerden kaçınmaları gerekmektedir. Örgütsel bağlılığın oluşturulmasında çalışanların örgütsel adalet algısı da önemli bir rol oynamaktadır. Bu yüzden örgütlerde adil bir ödül mekanizmasının geliştirilmesi, terfi fırsatlarının çalışanlara eşit bir şekilde sunulması örgütlerin başarısına katkı sağlayacaktır.

Örgütlerde insan kaynakları birimleri tarafından işe alıştırma eğitimlerinin verilmesi, çalışanın işine yönelik ve motivasyonunu arttırıcı eğitimler düzenlenmesi, çalışanlar arası iletişimi arttıracak aktivitelerin düzenlenmesi çalışanların örgüte olan bağlılığını pozitif yönde etkileyen bir unsurdur. Bu araştırmanın yapıldığı kurumda iş eğitimine yönelik ifadelerden en yüksek oranın amirler tarafından verilen talimatların çalışanların işlerini yapmasında kolaylık sağladığına ilişkin olduğu görülmektedir. Yani kurumda amirlerin bir usta görevi üstlendiği, daha informal taktikler uygulanarak işlerin öğretildiği kanısına ulaşılmaktadır. İnformal taktiklere ilave olarak düzenli olarak eğitim programlarının da örgütlerde düzenlenmesi, iş başlangıcında oryantasyon eğitimlerinin verilmesi bireyin örgüte uyumun hılandıran etmenlerdir. Araştırma örnekleminin belediye çalışanları olması örgütsel bağlılıklarının sağlanması açısından oldukça önemlidir. Çünkü belediye çalışanları halkla birebir iletişim içerisindedir. Yaptığı işi seven, o kurumda olmaktan mutluluk duyan ve uzun yıllar görevini yerine getirmeyi düşünen bir çalışan, o belediyenin verdiği hizmetin başarısını olumlu yönde etkileyecektir. Dolayısıyla çalışanların beklentilerine önem veren, çalışanların örgüte uyumu için çaba gösteren, çalışanlarıyla birlikte takım oluşturdukları hissini geliştiren örgütlerin başarılı olması beklenmektedir. 
EXTENDED ABSTRACT

\title{
The Interrelationship Among Organizational Socialization, Psychological Contract And Organizational Commitment: The Research In A Public Institution
}

\author{
* \\ Nazlı Türker - Mustafa Yıldırım \\ Alanya Alaaddin Keykubat University
}

Organizational socialization, which can be defined as an interaction process between the organization and the employee, in which the employee learns the organization's value systems, norms, and behavior patterns (Balc1, 2003, p.3); it enables the employee to transition from being an individual outside the organization to being an active member of the organization. Organizational socialization is generally considered as the transition of the new employee from an individual outside the organization to an active employee of the organization, but when the employee is appointed to a new task or assumes a new responsibility, he / she has to experience an organizational socialization process again (Van Maanen ve Schein, 1979, p.6-7).

Employees have some expectations from the organization when starting their job. Likewise, organizations employ employees with certain expectations. These expectations are mutually regulated by a non-written, invisible contract in addition to written contracts. Argyris [1960] first used the psychological contract to explain the relationship between employee and employer (Anderson ve Schalk, 1998, p.638).

Although different classifications are made regarding psychological contracts (Rousseau, 1995; Shore \& Barksdale, 1998); in the literature, it is seen that transactional and relational contracts are mostly examined as two dimensions of psychological contract. Transactional contracts, as short-term contracts with an economic dimension for the change of monetary factors. Relational contracts are defined as open-ended contracts that establish and maintain monetary and non-monetary relationships (Rousseau, 1990). 
Organizational commitment is a subject that is frequently examined by different disciplines and investigated in relation to many individual and organizational variables. An individual who feels commitment to the organization is expected to make more effort while performing his / her duty and work in that organization for many years.

Organizational socialization and psychological contract are very important concepts in terms of transforming new employees into active members of the organization and ensuring their commitment to the organization. When the previous studies on organizational socialization are examined, it is seen in the literature review that it has been studied mainly on the education sector and has been studied in terms of other sectors in recent years. It has been observed that there is a limited number of studies, especially in the public sector. In the literature review, it was seen that there are many studies that linked with the concepts of organizational socialization and psychological contract separately with organizational commitment. However, there are few studies that examine the concept of organizational socialization and psychological contract together. It is anticipated that the results of this study will be beneficial for public institutions. It is thought that this study will contribute to the further studies to be carried out on the public sector and private sector.

The purpose of this research is to determine the predictive relationships between the organizational socialization, psychological contracts and organizational commitment of the personnel working in Alanya Municipality. For this purpose, research hypotheses have been developed in line with the relevant theoretical framework and empirical results. Acoording to the research hypotheses, the effect of the organizational socialization levels of the participants on the transactional and relational psychological contracts; the effects of organizational socialization levels on the dimensions of organizational commitment and the effects transactional and relational contracts on organizational commitment dimensions are discussed. In the study, the survey technique was used as a data collection tool, and previously developed scales on all three subjects were used. When the demographic findings of the study were examined, it was seen that the majority of the employees participating in the survey were male, between the ages of 31-45, and were married. Although it is said that primary and high school graduates are predominant in terms of education 
levels, similar results were obtained. In terms of work experience, the employees have mostly $61-450$ months (5-37.5 years) of experience; $58 \%$ have 61-450 months (5-37.5 years) of working experience in the same institution and predominantly it has been observed that the participants have subcontracted status. It was observed that the employees participating in the research mostly worked in administrative jobs.

Regression analyzes were conducted to test the research hypotheses. According to the analysis, it is seen that organizational socialization has an effect on the relational contract and organizational socialization has an effect on organizational commitment. Also, it is found that psychological contract dimensions have an effect on organizational commitment.

This study is expected to contribute to the literature, since there are few studies on the relationship between organizational socialization, psychological contract, and organizational commitment. This study has been applied to an institution in the public sector. In order for the subject to be understood more clearly, a wider sample and application to different sectors is required.

\section{Kaynakça / References}

Afsanepurak, S. A., Hossini, R. N. S., Seyfari, M. K. ve Nasabi, Z. M. N. (2012). The relationship between organization socialization and organizational commitment in physical education departments employees in Mazandaran - Iran. International Journal of Academic Research in Business and Social Science, 2(1), 187195.

Agarwal, P. (2011). Relationship between, psychological contract \& organizational commitment in Indian IT Industry, The Indian Journal of Industrial Relations, 47(2), 290-305.

Agarwal, P. ve Sajid, S. M. (2017). A study of job satisfaction, organizational commitment and turnover intention among public and private sector employees. Journal of Management Research, 17(3), 123-136.

$\mathrm{Al}, \mathrm{A}$. (2007). Üniversitelerdeki yabanc diller birimleri yöneticilerinin yönetsel yeterlik düzeyi ile İngilizce öğretim elemanlarnnn örgütsel bağhllk düzeylerinin araş̧trnlması. Yayımlanmamış Yüksek Lisans Tezi. Kocaeli Üniversitesi Sosyal Bilimler Enstitüsü, Kocaeli.

Allen, N. J. ve Meyer, J. P. (1990). The measurement and antecedents of affective, continuance and normative commitment to the organization. Journal of Occupational Psychology, 63, 1-18. 
Aliyev, Y. (2014). Örgütsel sosyalleşme ve örgütsel özdeşleşme arasındaki ilişki: Bir araştırma. Yayınlanmamış Yüksek Lisans Tezi. Atatürk Üniversitesi Sosyal Bilimler Enstitüsü, Erzurum.

Anderson, N. ve Schalk, R. (1998). The psychological contract in retrospect and prospect. Journal of Organizational Behavior, 19, 637-647.

Aselage, J. ve Eisenberger, R. (2003). Perceived organizational support and psychological contracts: A theoretical integration. Journal of Organizational Behavior, 24, 491-509.

Avcı, N. ve Küçükusta D. (2009). Konaklama işletmelerinde örgütsel öğrenme, örgütsel bağlllık ve işten ayrılma eğilimi arasındaki ilişki. Anatolia: Turizm Araştırmalan Dergisi, 20(1), 33-44.

Balcı, A. (2003). Örgütsel sosyalleşme: kuram strateji ve taktikler (2. Baskı), Ankara: Pegem Akademi Yayıncılık.

Balcı, A., Baltacı, A., Fidan, T., Cereci, C. ve Acar, U. (2012). Örgütsel sosyalleşmenin, örgütsel özdeşleşme ve örgütsel vatandaşlıkla ilişkisi: ilköğretim okulu yöneticileri üzerinde bir araştırma. Eğitim Bilimleri Araştırmalan Dergisi, 2, 48-76.

Balfour, D. L. ve Wechsler, B. (1996). Organizational commitment: Antecedents and Outcomes in public organizations. Public Productivity \& Management Review, 19 (3), 256-277.

Bayram L. (2005). Yönetimde yeni bir paradigma: Örgütsel bağlllık. Sayıştay Dergisi, 59, 125-139.

Bilgili, H ve Tekìn, E. (2019). Örgütsel stres, örgütsel bağlllık ve öğrenilmiş güçlülük ilişkisi üzerine bir araştırma. OPUS Uluslararası Toplum Araştırmalan Dergisi, 11(18), 2165-2200. DOI: 10.26466/opus.557530

Buchanan, B. (1974). Building organizational commitment: The Socialization of managers in work organizations. Admistrative Science Quarterly, 19(4), 533-546.

Büyükbeşe, T., Çavuşoğlu, S. ve Okun, O. (2019). Otantik liderlik ile örgütsel bağlılık arasında psikolojik sermayenin aracılık rolü: Bingöl Üniversitesi örneği. OPUS Uluslararası Toplum Araştırmalarn Dergisi, 10(17), 194-225.

Chao, G. T., O'Leary - Kelly, A. M. , Wolf, S., Klein, H.J. ve Gardner, P. D. (1994). Organizational socialization: Its content and consequences. Journal of Applied Psychology, 79(5), 730-743.

Coyle-Shapiro, J. A. M. ve Kessler, I. (2003). The employment relationship in the UK public sector: A psychological contract perspective. Journal of Public Administration Research and Theory, 13(2), 213-230. 
Çerik, Ş. ve Bozkurt, S. (2010). Çalışanların örgütsel sosyalizasyon ve kariyer çapalarına yönelik algılamaları arasındaki ilişkinin incelenmesi ve banka çalışanlarına yönelik bir araştırma. Erciyes Üniversitesi Iktisadi ve İdari Bilimler Dergisi, 35, 77-97.

Çetin, C. ve Kurban, P. (2016). Tükenmişlik ve örgütsel sosyalleşme ilişkisi- kıdemi 0-2 yll olan memur çalışanlar örneklemi. Çalş̧ma ve Toplum Dergisi, 3, 1271- 1294.

Çiçeklioğlu, H. ve Taşlıyan, M. (2018). Psikolojik Sözleşme ve Presenteeism İlişkisi: Bir Alan Araştırması. International Journal of Disciplines Economics \& Administrative Sciences Studies, 4(9), 474-484.

Coşkun, R., Altunışık, R. ve Yıldırım, E. (2017). Sosyal bilimlerde araştırma yöntemleri: SPSS uygulamalı. 9. Baskı, Sakarya Yayıncilik.

Dabos, G. E. ve Rousseau, D. M. (2013). Psychological contracts and informal networks in organizations: The effects of social status and local ties. Human Resource Management, 52(4),485-510.

DeBode, J. D., Mossholder, K. W. ve Walker, A. G. (2017). Fulfilling employees' psychological contracts: Organizational socialization's role. Leadership \& Organization Development Journal, 38(1), 42-55.

De Vos, A., Buyens, D. ve Schalk, R. (2003). Psychological contract development during organizational socialization adaptation to reality and the role of reciprocity. Journal of Organizational Behavior, 24(5, SpecIssue), 537-559.

Demiral, Ö. (2008). Örgütsel bağ̆lliğrn sağlanmastnda personel güçlendirme ve psikolojik sözleşmenin etkisine ilişkin bir araştırma. Yayınlanmamış Yüksek Lisans Tezi. Niğde Üniversitesi Sosyal Bilimler Enstitüsü, Niğde.

Demirkasımoğlu, N. (2012). Kamu ve özel ilköğretim okulu simf öğretmenlerinin psikolojik sözleşme algulan ve iş çeoresine uyum düzeyleri ilişkisi. Doktora Tezi, Ankara Üniversitesi Eğitim Bilimleri Enstitüsü, Ankara.

Estreder, Y., Tomás, I., Chambel, M. J. ve Ramos, J. (2019). Psychological contract and attitudinal outcomes: multilevel mediation model. Personnel Review, 48(7), $1685-1700$

Feldman, D. C. (1976). A contingency theory of organizational socialization. Administrative Science Quarterly, 21, 433-452.

Fisher, C. D. (1986). Organizational socialization: An integrative review. K. M. Rowland \& G.R. Ferris (ed.), Research in Personel and Human Resources Management, içinde (s.101-145) Greenwich, CT: JAI Press.

Gökçen Kapusuz, A. (2019). İş hayatında duygusal zekâ perspektifinden örgütsel sosyalleşme süreci. Manas Sosyal Araşttrmalar Dergisi, 8(1), 231-245.

Grusky, O. (1966). Career mobility and organizational commitment. Administrative Science Quarterly, 10, 489-503. 
Guest, D. E. (1998). Is the psychological contract worth taking seriously? Journal of Organizational Behavior, 19, 649-664.

Gül, H. (2002). Örgütsel bağlılik yaklaşımlarının mukayesesi ve değerlendirmesi. Ege Akademik Bakış Dergisi, 2(1), 37-55.

Gül, H. (2003). Karizmatik liderlik ve örgütsel bağhllık ilişkisi üzerine bir araştırma. Doktora Tezi. Gebze Yüksek Teknoloji Enstitüsü Sosyal Bilimler Enstitüsü, Gebze.

Hassan, Z., Abdul-Rahman, A., ve Basit, A. (2017). The impact of psychological contract on organisational commitment: A study on public sector of Maldives. Available at SSRN 3056216.

Hiltrop, J. M. (1995). The changing psychological contract: The human resource challenge of the 1990s. European Management Journal, 13(3), 286-294.

Jones, G. R. (1986). Socialization tactics, self-afficiency and newcomers adjustments to organizations. Academy of Management Journal, 29(2), 262-279.

Kanter, R. M. (1968). Commitment and social organization: a study of commitment mechanisms in utopian communities. American Sociological Review, 33(4), 499-517.

Karcıoğlu F. ve Türker, E. (2010). Psikolojik sözleşme ve örgütsel bağlllık ilişkisi: Sağlık çalışanları üzerine bir uygulama. Atatürk Üniversitesi İktisadi ve İdari Bilimler Dergisi, 24(2), 121-140.

Kim, K. ve Moon, H. K. (2019). How do socialization tactics and supervisor behaviors influence newcomers' psychological contract formation? The mediating role of information acquisition. The International Journal of Human Resource Management, 1-27. https://doi.org/10.1080/09585192.2018.1521460

Kotter, J. P. (1973). The psychological contract: Managing the joining - up process. California Management Review, XV (3), 91-99.

Louis, M. R. (1980b). Surprise and sense making: What newcomers experience in entering unfamiliar organizational settings. Administrative Science Quarterly, 25, 226-251.

Macit, M ve Ekim, H. (2020). Psikolojik sözleşme algısının örgütsel bağlllık üzerine etkisi: Sağlık çalışanları üzerinde bir araştırma. Sosyal Bilimler Araştırmalan Dergisi, 15(1), 323-333. https://dergipark.org.tr/tr/pub/gopsbad/issue/55182/687267 adresinden erişilmiştir.

Manuti, A., Spinelli, C. ve Giancaspro, M. L. (2016). Organizational socialization and psychological contract: The vulnerability of temporary newcomers, a case study from an Italian Call Center. Employ Respons Rights, 28, 225-245.

Meyer, J. P. ve Allen, N. J. (1991). A three-component conceptualization of organizational commitment. Human Resource Management Review, 1(1), 61-89. 
Meyer, J. P., Allen, N. J. ve Smith, C. A. (1993). Commitment to organizations and occupations: Extension and test of a three-component conceptualization. Journal of Applied Psychology, 78(4), 538-551.

Meyer, J. P., Irving, P. G. ve Allen, N. J. (1998). Examination of the combined effects of work values and early work experiences on organizational commitment. Journal of Organizational Behavior, 19(1), 29-52.

Millward, L. J. ve Hopkins L. J. (1998). Psychological contracts, organizational and job commitment. Journal of Applied Social Psychology, 28(16), 1530-1556.

Mitus, J. S. (2006). Organizational socialization from a content perspective and its effect on the affective commitment of newly hired rehabilitation counselors. Journal of Rehabilitation, 72(2), 12-20.

Morrison, E. W. (1993). Longitudinal study of effects of information seeking on newcomer socialization. Journal of Applied Psychology, 78 (2), 173-183.

Ostroff, C. ve Kozlowski, S. J. (1992). Organizational socialization as a learning process: The role of information acquisition. Personel Psychology, 45, 849-874.

Özçelik, F. (2008). Örgütsel Sosyalleşmenin Örgütsel Bağhlhğa Etkisi: Bir uygulama. Yayımlanmamış Yüksek Lisans Tezi. Marmara Üniversitesi Sosyal Bilimler Enstitüsü, İstanbul.

Özgen Mimaroğlu H. ve Özgen, H. (2010). Psikolojik sözleşme ve boyutlarını iş tatmini, örgütsel bağlllık ve işten ayrılma niyetine etkileri: Tibbi satş temsilcileri üzerinde bir araştırma. Çukurova Üniversitesi Sosyal Bilimler Enstitüsü Dergisi, 19(1), 1-19.

Özler, D., E. ve Ünver, E. (2012). Psikolojik sözleşmenin iş tatmini üzerindeki etkisini belirlemeye yönelik bir araştırma. Süleyman Demirel Üniversitesi İktisadi ve İdari Bilimler Fakültesi Dergisi, 17 (2), 325-351.

Özutku, H. (2008). Örgüte duygusal, devamlllık ve normatif bağllık ve iş performansı arasındaki ilişkinin incelenmesi. İstanbul Üniversitesi İşletme Fakültesi Dergisi, 37(2), 79-97.

Parzefall, M. ve Hakanen, J. (2010). Psychological contract and its motivational and health-enhancing properties. Journal of Managerial Psychology, 25(1), 421. https://doi.org/10.1108/02683941011013849

Polat, S. ve Uğurlu, C. T. (2009). İköğretim müfettişlerinin örgütsel bağlllk, mesleki tükenmişlik ve işten ayrlma niyetleri arasındaki ilişki. E- Journal of New World Sciences Academy, 4 (3), 1150-1159.

Reichers, A. E. (1985). A review and reconceptualization of organizational commitment. Academy of Management Review, 10(3), 465-476. 
Robinson, S. L. (1996). Trust and breach of the psychological contract. Administrative Science Quarterly, 41, 574-599.

Robinson, S. L., Kraatz, M. S. ve Rousseau, D. M. (1994). Changing obligations and the psychological contract: A longitudinal study. Academy of Management Journal, 37(1), 137-152.

Robinson, S., L. ve Rousseau, D., M. (1994). Violating the psychological contract: Not the exception but the norm. Journal of Organizational Behavior, 15(3),245-259.

Rousseau, D. M. (1990). New hire perception of their own and their employer's obligations: A study of psychological contracts. Journal of Organizational Behavior, 11, 389-400.

Rousseau, D. M. (1995). Psychological contracts in organizations: Understanding written and unwritten agreements. Thousand Oaks. CA: Sage.

Rousseau, D. M. (2001). Schema, promise and mutuality: The building blocks of the psychological contract. Journal of Occupational and Organizational Psychology,74, 511541.

Shore, L. M. ve Barksdale, K. (1998). Examining the degree of balance and level of obligation in the employment relationship: A social exchange approach. Journal of Organizational Behavior, 19, 731-744.

Soares, M. E. ve Mosquera, P. (2019). Fostering work engagement: The role of the psychological contract. Journal of Business Research, 101, 469-476.

Sürgevil, O. (2007). Çalışma yaşamında örgütsel bağhlık. Yayımlanmamış Yüksek Lisans Tezi. Ege Üniversitesi Sosyal Bilimler Enstitüsü, İzmir.

Sturges, J., Conway, N., Guest, D., and Liefooghe, A. (2005). Managing the career deal: The psychological contract as a framework for understanding career management, organizational commitment and work behavior. Journal of Organizational Behavior, 26(7), 821-838. https://doi.org/10.1002/job.341

Taormina, R. J. (1994). The organizational socialization Inventory. International Journal of Selection and Assesment, 2, 133-145.

Taormina, R. J. (1997). Organizational socialization: A multidomain, continous process model. International Journal of Selection and Assesment, 5(1), $29-47$.

Taormina, R.J. ve Law, C., M. (2000). Approaches to preventing burnout: The effects of personal stress management and organizational socialization. Journal of Nursing Management, 8, 89-99.

Taormina, R. J. (2004). Convergent validation of two masures of organizational socialization. International Journal of Human Resource Management, 15 (1), 76-94 
Tekleab, A. G., Orvis, K. A. ve Taylor, M. S. (2013). Deleterious consequences of change in newcomers' employer - based psychological contract obligations. Journal of Business \& Psychology, 28, 361-374.

Tetik. S. (2019). Kamu örgütlerinde örgütsel sosyalleşmenin iş motivasyonu üzerindeki etkisi: İhsaniye ilçesinde bir araştırma. İşletme Araştırmalan Dergisi,11(3),17791791.

Thomas, D. C. ve Anderson, N. (1998). Changes in newcomers' psychological contracts during organizational socialization: A study of recruits entering The British Army. Journal of Organizational Behavior, 19, 745-767.

Thomas, H. D. C. ve Anderson, N. (2005). Organizational socialization: A field study into success and rate. International Journal of Selection and Assessment, 13(2), 116-128.

Tsui, P. L., Lin, Y. S. ve Yu, T. H. (2013). The influence of psychological contract and organizational commitment on hospitality employee performance. Social Behavior and Personality, 41(3), 443-452.

Ulukapı Yllmaz, H. ve Yllmaz, A. (2016). The effect of organizational socialization on organizational commitment: The mediation role of psychological empowerment. Journal of Human Sciences, 13(3), 6204-6219.

Uyguç, N. ve Çımrın, D. (2004). DEU araştırma ve uygulama hastanesi merkez laboratuvarı çalışanlarını örgüte bağllıklarını ve işten ayrılma niyetlerini etkileyen faktörler. Dokuz Eylül Üniversitesi İktisadi ve İdari Bilimler Fakültesi Dergisi, 19(1), 91-99.

Van Maanen, J. ve Schein, E. (1979). Toward a theory of organizational socialization. In B. M. Staw (Ed.), Research In Organizational Behavior, 1. cilt içinde (s.209-264). Greenwich, CT: JAI Press. 16.04.2018 tarihinde https://dspace.mit.edu/bitstream/handle/1721.1/1934/SWP-0960-03581864.pdf adresinden erişilmiştir.

Van Maanen, J. (1978). People processing: strategies of organizational socialization. Organizational Dynamics, Summer, 19-36.

Valaei, N. ve Rezaei, S. (2016). Job satisfaction and organizational commitment: An empirical investigation among ICT-SMEs. Management Research Review, 39(12), 1663-1694. https://doi.org/10.1108/MRR-09-2015-0216

Wanous, J. P. (1980). Organizational entry: Recruitment, selection and socialization of Newcomers. Massachusetts: Addison-Wesley Publishing Company.

Wasti, S.A., (2000). Meyer ve Allen'in üç boyutlu örgütsel bağlllk ölçeğinin geçerlilik ve güvenirlilik analizi. VIII Ulusal Yönetim ve Organizasyon Kongresi Bildirisi, Nevşehir.

Woodrow, C. ve Guest, D. E. (2017). Knowledge acquisiton and effective socialization: The role of the psychological contract. Journal of Occupational and Organizational Psychology, 90(4), 587-595. 
Woodrow, C. ve Guest, D. E. (2020). Pathways through organizational socialization: A longitudinal qualitative study based on the psychological contract. Journal of Occupational and Organizational Psychology, 93(1), 110-133.

Yazgan, A., ve Özer Topaloğlu, E. (2020). Örgütsel belirsizliğin örgütsel bağlllı üzerindeki etkisinde örgütsel stresin aracllk rolü. OPUS Uluslararast Toplum Araştrrmalan Dergisi, 16 (28), 1272-1295. DOI: 10.26466/opus.748687

Yıldırım, S. (2014). İşörenlerin örgütsel sosyalleşme düzeylerinin işten ayrlma eğilimleriyle ilişkisi ve bir araştırma. Yayımlanmamış Yüksek Lisans Tezi. Marmara Üniversitesi Sosyal Bilimler Enstitüsü, İstanbul.

Yılmaz, A. (2012). Psikolojik sözleşme ve örgütsel gü̈ven arasindaki ilişkinin analizi: Teorik ve uygulamal bir çalışma. Yayımlanmamış Yüksek Lisans Tezi. Selçuk Üniversitesi Sosyal Bilimler Enstitüsü, Konya.

Zhou, J. W., Plaisent, M., Zheng, L.L.ve Bernard, P. (2014). Psychological contract, organizational commitment and work satisfaction: Survey of researchers in Chinese state-owned engineering research institutions, Open Journal of Social Sciences, 2, 217-225. http://dx.doi.org/10.4236/jss.2014.29037

Zonana, M. (2011). İş Stresinin işgörenlerin örgütsel sosyalleşme düzeylerine etkileri ve bir araştırma. Yayınlanmamış Yüksek Lisans Tezi. Marmara Üniversitesi Sosyal Bilimler Enstitüsü, İstanbul.

\section{Kaynakça Bilgisi / Citation Information}

Türker, N. ve Ylldırım, M. (2020). Örgütsel sosyalleşmenin psikolojik sözleşme ve örgütsel bağlllıkla ilişkisi: Bir kamu kurumunda araştırma. OPUSUluslararası Toplum Araştırmaları Dergisi, 16(Eğitim ve Toplum), 60696105. DOI: 10.26466/opus.674201 